\title{
Recent Advances in Non-Flammable Electrolytes for Safer Lithium-Ion Batteries
}

\author{
Neha Chawla ${ }^{1, *(D)}$, Neelam Bharti ${ }^{2}$ and Shailendra Singh ${ }^{1}$ \\ 1 Environmental, Health and Safety, Carnegie Mellon University, Pittsburgh, PA 15213, USA; \\ shailen2@andrew.cmu.edu \\ 2 Mellon Institute Library, Carnegie Mellon University, Pittsburgh, PA 15213, USA; \\ nbharti@andrew.cmu.edu \\ * Correspondence: nehac@andrew.cmu.edu
}

Received: 19 December 2018; Accepted: 17 January 2019; Published: 1 February 2019

check for updates

\begin{abstract}
Lithium-ion batteries are the most commonly used source of power for modern electronic devices. However, their safety became a topic of concern after reports of the devices catching fire due to battery failure. Making safer batteries is of utmost importance, and several researchers are trying to modify various aspects in the battery to make it safer without affecting the performance of the battery. Electrolytes are one of the most important parts of the battery since they are responsible for the conduction of ions between the electrodes. In this paper, we discuss the different non-flammable electrolytes that were developed recently for safer lithium-ion battery applications.
\end{abstract}

Keywords: lithium-ion battery; non-flammable; electrolyte; safety; battery fire

\section{Introduction}

Rechargeable lithium-ion (Li-ion) batteries are widely used in portable electronic devices and are considered as the most potential power source for electric vehicles due to their high energy density and long cycle life. A Li-ion battery consists of a positively charged cathode, negatively charged anode, separator, electrolyte, and positive and negative current collectors. While discharging, the lithium ions travel from the anode to the cathode through the electrolyte, thus generating an electric current, and, while charging the device, lithium ions are released by the cathode and then go back to the anode. Figure 1 shows the basic working principle of a Li-ion battery. Since the electrolyte is the key component in batteries, it affects the electro-chemical performance and safety of the batteries.
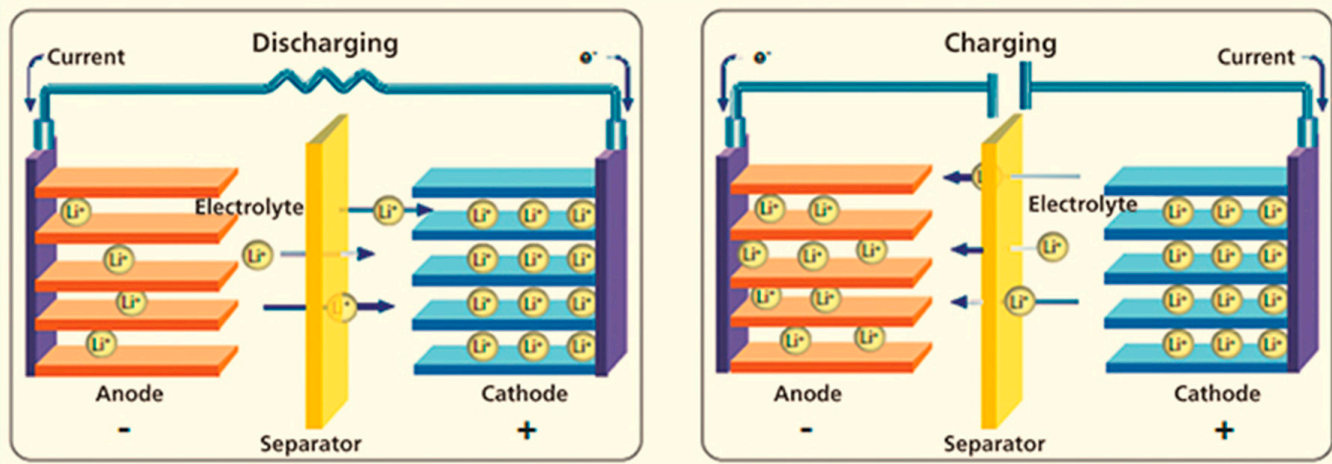

Figure 1. Basic working principle of a lithium-ion (Li-ion) battery [1].

The most common devices we use, such as cell phones and other common electronics, use Li-ion batteries. Recently, several accidents were reported due to Li-ion battery failure. In the past few years, 
several cases were reported where cell phones, laptops, hoverboards, etc. caught fire due to Li-ion battery failure. According to a news report, there were 92 cases of Samsung Galaxy Note fires, 26 burns, and 55 property damages [2]. The Federal Aviation Administration (FAA) reported that the Li-ion battery accidents increased from 31 incidents in 2016 to 46 incidents in 2018 [3]. As per the FAA report, one Li-ion battery "incident" occurs every 10 days either on airplanes or at airports. In 2010, a United Postal Service (UPS) cargo plane crashed in the United Arab Emirates because of a fire caused by a shipment of Li-ion batteries in the cargo hold [4]. In November 2017, the Li-ion battery of a camera exploded at Orlando International Airport at a security checkpoint, which caused a terminal to be evacuated [5]. A Li-ion battery-containing device exploded and caught fire in a passenger suitcase loaded in the cargo on a Delta Connection/SkyWest flight [6]. A battery-operated vape pen caught fire during a Transportation Security Administration (TSA) X-ray screening at Denver International Airport in January 2018. In another incident, in January 2018, a lithium-battery power bank caught fire on a flight that was scheduled to depart to Shanghai. Recently, there were several reports of Tesla vehicles catching fire [7]. In June 2018, a battery pack of Tesla Model S caught fire resulting in a casualty [7]. In 2016, the same model also caught fire during a test drive event in France [8].

A battery under normal work conditions consists of organic solvents and lithium salt. Water and heat cause the thermal dissociation of $\mathrm{LiPF}_{6}$, the produced Lewis acid $\mathrm{PF}_{5}$ attacks the solvent molecules, and the combustion of large amounts of active free radicals leads to thermal runaway. Li-ion battery fires are typically a result of heat generated due to a short circuit within one or more of the battery's cells. Generated heat in the cell ignites the chemicals within the battery, which leads to "thermal runaway". Thermal runaway temperatures can go as high as $1000^{\circ} \mathrm{F}$, creating intense pressures inside the battery, leading to an explosion in the flammable liquid electrolyte. Figure 2 shows the schematic representation of a thermal runaway process [9].

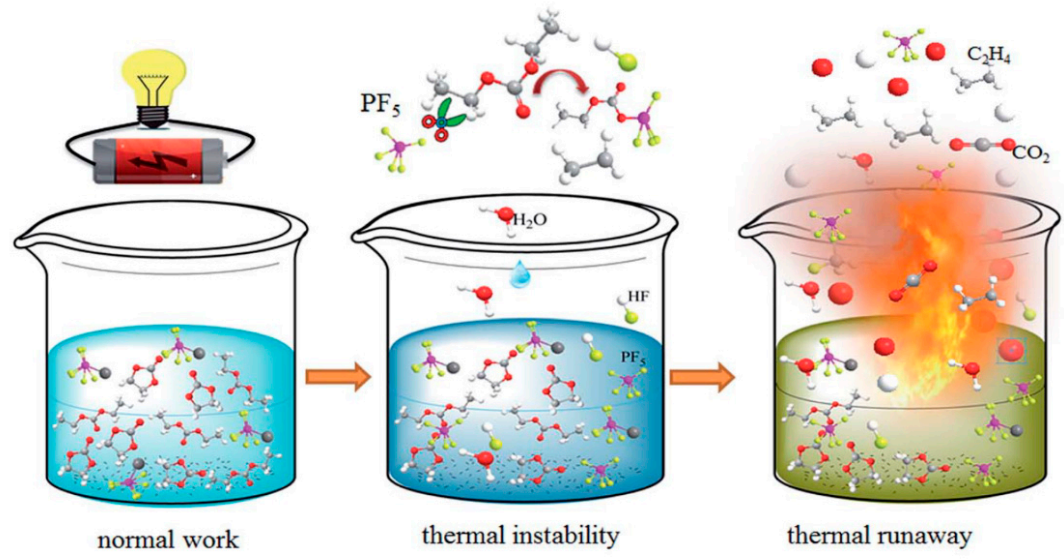

$\mathrm{OOC} \mathrm{OH} \odot \mathrm{F} \odot \mathrm{P}$

Figure 2. Schematic of the thermal runaway process of the Li-ion battery electrolyte [9]. Republished with permission of the Royal Society of Chemistry, from A self-cooling and flame-retardant electrolyte for safer lithium-ion batteries; Lihua Jiang, Qingsong Wang, Ke Li, Ping Ping, Lin Jianga, and Jinhua Sun; 2, and (C) 2018; permission conveyed through Copyright Clearance Center, Inc.

As the demand for Li-ion batteries (LIBs) is increasing, the safety concerns of the conventional carbonate-based electrolytes also increased in the commercial LIBs. Developing new electrolyte systems with improved safety features is one of the high priorities being investigated by several researchers. Conventional electrolytes are mostly composed of lithium hexafluorophosphate $\left(\mathrm{LiPF}_{6}\right)$ dissolved in a mixture of ethylene carbonate (EC) and linear carbonates [3]. Carbonates have high volatility and flammability. However, the high flammability of linear carbonates, such as diethyl carbonate (DEC), dimethyl carbonate (DMC), and ethyl methyl carbonate (EMC), is the biggest safety concern of lithium-ion batteries [10]. To date, researchers made several efforts to formulate safe electrolytes with 
enhanced battery performances [11-14]. In this review article, we compile literature and discuss a few recent advances in electrolyte formulation toward safe Li-ion batteries.

\section{Results and Discussion}

\subsection{Organosilicon-Containing Electrolytes}

Organosilicon compounds are compounds with carbon-silicon bonds. They receive considerable attention as electrolytic solvents for energy storage devices because of their low flammability, high thermal and electrochemical stability, and environmentally benign characteristics. Wang et al. synthesized two fluorosilanes with oligo(ethylene oxide) units through hydrosilylation of chlorosilane with allyl substituted oligo(ethylene oxide) ether, followed by fluorination with potassium fluoride, namely fluoro(3-(2-(2-methoxyethoxy)ethoxy)propyl) dimethylsilane $\left(\mathrm{MFSM}_{2}\right)$ and difluoro(3-(2-(2-methoxyethoxy)ethoxy)propyl) methylsilane $\left(\mathrm{DFSM}_{2}\right)$ [11]. The fluorination resulted in lowering the viscosity, and increasing the dielectric constant and oxidative potential as compared to their non-fluorinated counterparts. $\mathrm{DFSM}_{2}$-doped electrolyte exhibited high voltage and improved thermal stability when used with a lithiated graphite anode and a delithiated $\mathrm{LiCoO}_{2}$ cathode, making it a safe electrolyte for lithium-ion batteries. The electrolyte, $1 \mathrm{M} \mathrm{LiPF}_{6}$ (lithium hexafluorophosphate) in $\mathrm{EC} / \mathrm{DFSM}_{2} / \mathrm{EMC}(v / v / v=2 / 3 / 5)$ (ethylene carbonate/difluoro(3-(2-(2-methoxyethoxy)ethoxy)propyl) methylsilane/ethyl methyl carbonate) with the addition of $5 \mathrm{wt} . \%$ fluoroethylene carbonate (FEC) displayed an improved voltage limit, which led to a cyclability performance with $92.5 \%$ capacity retention at a voltage cutoff of $4.4 \mathrm{~V}$ after 135 cycles in a $\mathrm{LiCoO}_{2}(\mathrm{LCO}) /$ graphite full cell [11].

\subsection{Ionic Liquid Electrolytes with/without Solvents}

Ionic liquids are salts with poorly coordinated ions, resulting in these solvents being liquid below $100{ }^{\circ} \mathrm{C}$, or even at room temperature. Ionic liquids received great attention recently for their use in batteries. Ionic liquids (ILs) have low volatility, are non-flammable, and have high electrochemical and thermal stabilities, due to which they are used for energy storage and conversion applications, such as super capacitors, solar cells, and batteries [15-17]. Three choline-based ionic liquids functionalized with trimethylsilyl, allyl, and cyanoethyl groups for high-voltage Li-ion batteries [12] were achieved via a two-step method that consisted of an anion exchange reaction of chlorine ion with LiTFSI (lithium bis (trimethylsulfonyl) imide) and a functionalization reaction with hexamethylsilazane, allyl bromide, and acrylonitrile [12]. The hybrid electrolyte was constructed by doping with $0.6 \mathrm{M} \mathrm{LiPF}_{6} / 0.4 \mathrm{M}$ lithium oxalydifluoroborate (LiODFB) as salts and dimethyl carbonate (DMC) as a co-solvent. Thermal properties of the electrolytes were found with the thermal decomposing temperatures in the order of AN1IL-TFSI $\left(325^{\circ} \mathrm{C}\right)<\mathrm{CEN1IL-TFSI}\left(330^{\circ} \mathrm{C}\right)<\mathrm{SN} 1 \mathrm{IL}-\mathrm{TFSI}\left(336^{\circ} \mathrm{C}\right)$ (AN1IL-TFSI (IL with allyl group), CEN1IL-TFSI (IL with cynoethyl group, SN1IL((2-trimethylsililoxyethyl) trimethylammonium bis(trifluoromethanesulf-onyl)imide). $\mathrm{An} \mathrm{LiCoO}_{2} /$ graphite full cell using SN1IL/DMC $(v / v=1 / 1)$ doped with $0.6 \mathrm{M} \mathrm{LiPF}_{6} / 0.4 \mathrm{M} \mathrm{LiODFB}$ (lithium oxalydifluoroborate) salts showed a cyclability of over 90 cycles with a capacity of $152 \mathrm{mAh} \cdot \mathrm{g}^{-1}$, a voltage cut-off of $4.4 \mathrm{~V}$ with good rate capability, retaining $72 \%$ capacity of $0.2 \mathrm{C}$ at the $2 \mathrm{C}$ rate. Only one-quarter of the propagation rate of the electrolyte was obtained as compared to commercial reference electrolyte $\left(1 \mathrm{M} \mathrm{LiPF}_{6} \mathrm{EC} / \mathrm{DEC} / \mathrm{DMC}, v / v / v=1 / 1 / 1\right)$, which is a good safety feature.

To design and develop safer and high-energy-density Li-ion batteries, Moreno et al. developed an electrolyte comprising PYR13TFSI/PYR13FSI ionic liquid with LiTFSI salt, where PYR13 stands for $N$-methyl- $N$-propyl pyrrolidinium, TFSI is bis(trifluoromethanesulfonyl)imide, and FSI is bis(fluorosulfonyl) imide [18]. The electrolyte exhibited a good ionic conductivity even at $-20{ }^{\circ} \mathrm{C}$ with an average electrochemical stability window of $5 \mathrm{~V}$. Electrolytes were also developed by mixing ethylene carbonate (EC) with ionic liquids based on ringed ammonium cations with ring sizes of 7, 6, and 5, i.e., azepanium, piperidinium, and pyrrolidinium, respectively [13]. The designed 
electrolytes had lower viscosities, improved conductivity, and better stability as compared to ionic liquids. Ionic liquids have good thermal stability, whereas EC is flammable; the electrolyte obtained by combining the two components was non-flammable and exhibited good thermal stability above $130^{\circ} \mathrm{C}$. $\mathrm{Li} / \mathrm{LiMn}_{1.5} \mathrm{Ni}_{0.5} \mathrm{O}_{4}(\mathrm{LMNO})$ and graphite/Li half batteries were fabricated with a fluoroethylene carbonate additive which led to discharge capacities of approximately 115 and $287 \mathrm{mAh} \cdot \mathrm{g}^{-1}$ at Coulombic efficiencies of $95 \%$ and $99 \%$, respectively, over 100 cycles at a rate of C/12.

$\mathrm{Li}$-ion batteries were prepared and tested by Gao et al. with an inorganic non-aqueous liquid electrolyte/ $\mathrm{LiAlCl}_{4,3} \mathrm{SO}_{2}$ (IE) and $\mathrm{LiFePO}_{4}$ cathode [14]. The batteries displayed stable cycling, higher discharge capacity, and better performance as compared to batteries with organic electrolytes. The ionic conductivity of the electrolyte was found to be better than organic electrolyte and it exhibited better safety performance and non-flammability.

\subsection{Flame-Retardant Solvents}

Flame-retardant solvents generally compromise the battery performance [19-22]. To explore this idea, Wang et al. studied an organic electrolyte using a sodium or lithium salt and trimethyl phosphate (TMP) [23]. TMP was used as a solvent because it is identified as a good flame retardant and has high oxidative stability and low viscosity [23]. At the $\mathrm{C} / 5$ rate, they obtained 1000+ cycles (over one year) with almost zero degradation when cycling with carbon/graphite anodes for sodium-ion/Li-ion batteries. $\mathrm{NaFSA} / \mathrm{LiFSA}\left(\mathrm{NaN}\left(\mathrm{SO}_{2} \mathrm{~F}\right)_{2} / \mathrm{LiN}\left(\mathrm{SO}_{2} \mathrm{~F}\right)_{2}\right)$ salts were used due to weak cation-anion interactions, which offer high ion transport even at elevated concentrations. Figure 3 shows the flame test of NaFSA/TMP. When used in a battery with a composition of $5 \mathrm{~V}$ class $\mathrm{LiNi}_{0.5} \mathrm{Mn}_{1.5} \mathrm{O}_{4} /$ graphite, the electrolyte exhibited a stable 100 cycles of discharge/charge at C/5. During the study, obtained Coulombic efficiency was $99.2 \%$, thus indicating its potential application for safe and high-voltage Li-ion batteries.

a
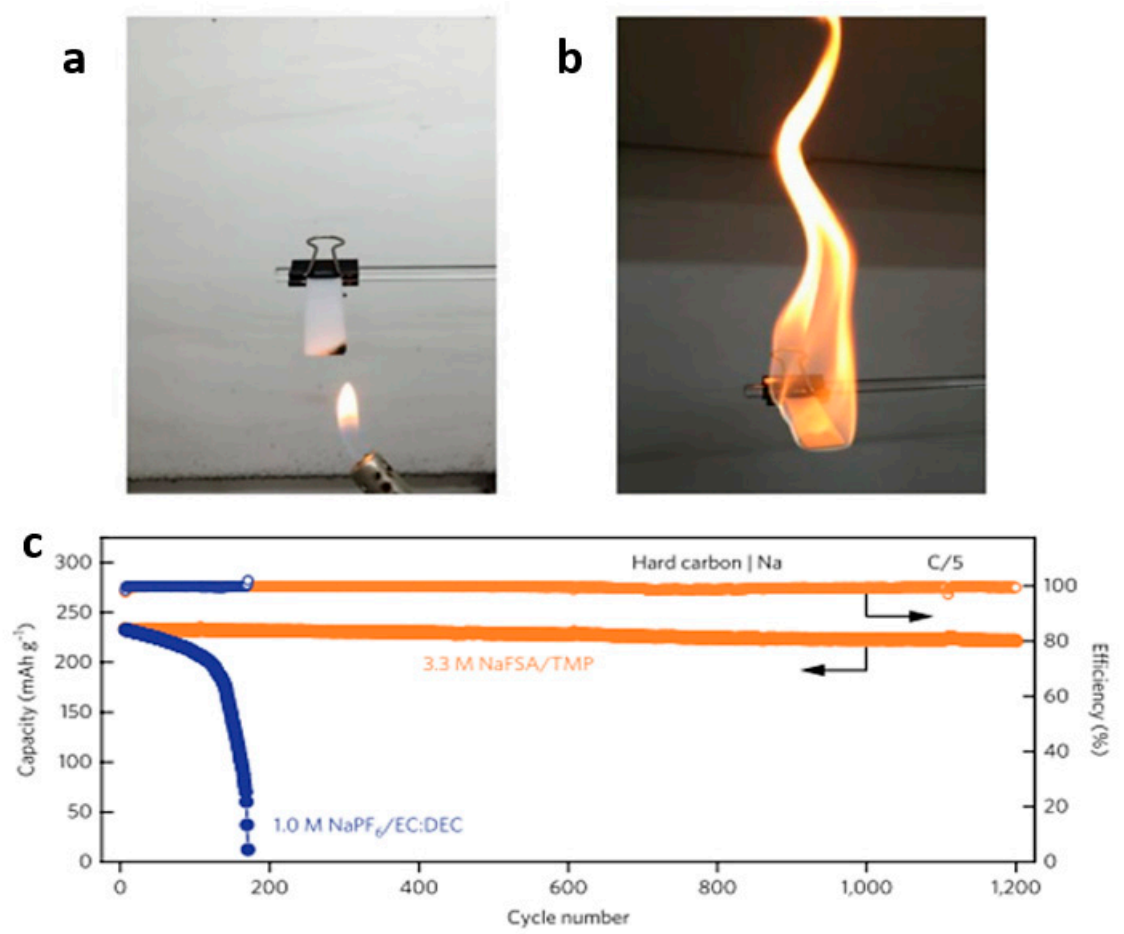

b

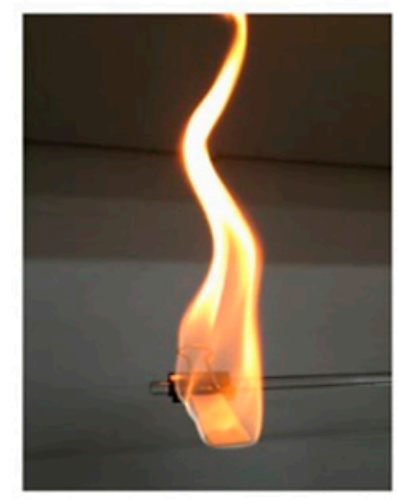

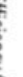

(1) 
Adiponitrile (ADN) is considered as a safe electrolyte because it is chemically stable and has a high boiling and flash point and low vapor pressure. ADN was used as a single-electrolyte solvent with lithium bis(trimethylsulfonyl)imide (LiTFSI) since it exhibits high electrochemical stability, indicating its potential as a suitable electrolyte for safer $\mathrm{Li}$ ions cells without compromising the performance [24]. $\mathrm{Li}_{4} \mathrm{Ti}_{5} \mathrm{O}_{12}$ (LTO) anode and $\mathrm{LiNi}_{1 / 3} \mathrm{Co}_{1 / 3} \mathrm{Mn}_{1 / 3} \mathrm{O}_{2}$ (NMC) cathode batteries exhibited a capacity of $165 \mathrm{mAh} \cdot \mathrm{g}^{-1}$ at a rate of $0.1 \mathrm{C}$, and more than $98 \%$ capacity was retained after 200 cycles at a rate of 0.5C [25]. ADN also provides excellent temperature stability from $-30^{\circ} \mathrm{C}$ to $180^{\circ} \mathrm{C}$.

\subsection{Fire-Extinguishing Electrolyte}

A new trend in the search for safer batteries is to design self-cooling and flame-retarding electrolytes for the battery. According to Jiang et al., "cooling is the key to curbing thermal runaway and compatibility is the basis to ensure electrochemical performance" [9]. They designed a self-cooling composite electrolyte which possessed flame-retardant properties. The thermal stability of the proposed electrolyte was improved by adding $N, N$-dimethylacetamide (DMAC) as a Lewis base and perfluoro-2-methyl-3-pentanone (PFMP) as a self-cooling micro-fire-extinguisher. Fluorocarbon surfactant (FS) was introduced to improve the interface compatibility and electrochemical performance of the battery. The improved thermal stability and electrochemical performance of the $\mathrm{Li} / \mathrm{C}$ and $\mathrm{NMC} / \mathrm{Li}$ half cells and full cells were observed with the developed electrolyte. Shi et al. synthesized the electrolyte by mixing propylene carbonate with 1,1,2,2-tetrafluoroethyl-2,2,3,3-tetrafluoropropyl ether at $25{ }^{\circ} \mathrm{C}$ with a conductivity of $5.04 \mathrm{mS} \cdot \mathrm{cm}^{-1}$ [16]. This electrolyte exhibited good safety features and wettability to electrodes and separator. The batteries also exhibited decent cycle performance at high $\left(60{ }^{\circ} \mathrm{C}\right)$ and low temperature $\left(-40{ }^{\circ} \mathrm{C}\right)$. They also synthesized a non-flammable hydrofluoroether electrolyte, 1,1,2,2-tetrafluoroethyl-2,2,3,3-tetrafluoropropyl ether (F-EPE), by mixing lithium bis(oxalato)borate (LiBOB) and gamma-butyrolactone(GBL) for Li-ion batteries [10]. The addition of F-EPE to the electrolyte exhibited an increased level of safety, decreased surface tension, and good wettability. The electrolyte supported the graphite $/ \mathrm{LiCo}_{1 / 3} \mathrm{Mn}_{1 / 3} \mathrm{Ni}_{1 / 3} \mathrm{O}_{2}$ full cell in achieving capacity retention of $80.6 \%$ after 500 cycles at room temperature. The battery also delivered a high capacity of $74.2 \mathrm{mAh} \cdot \mathrm{g}^{-1}$ at $40^{\circ} \mathrm{C}$.

\subsection{Fluorinated/Phosphonate Electrolyte}

Fluorinated/phosphonate-based electrolytes are discussed in this section. The flammability of two thermally stable and non-flammable all-fluorinated electrolytes that do not burn on ignition was compared by Fan et al. [26]. The electrolyte was made up of $1 \mathrm{M}$ lithium hexafluorophosphate $\left(\mathrm{LiPF}_{6}\right)$ in fluoroethylene carbonate/3,3,3-fluoroethylmethyl carbonate/1,1,2,2-tetrafluoroethyl-2', 2' ,2'-trifluoroethyl ether (FEC:FEMC:HFE, $w / w / w=2 / 6 / 2$ ). Figure 4 shows the comparison of the flammability tests of $1 \mathrm{M}$ $\mathrm{LiPF}_{6} \mathrm{EC} / \mathrm{DMC}, 1 \mathrm{M} \mathrm{LiPF}_{6} \mathrm{FEC} / \mathrm{DMC}$, and $1 \mathrm{M} \mathrm{LiPF}_{6} \mathrm{FEC} / \mathrm{FEMC} / \mathrm{HFE}$. It was determined that the fluorine substitution on the alkyl moiety inhibited the propagation of oxygen radicals during combustion. 

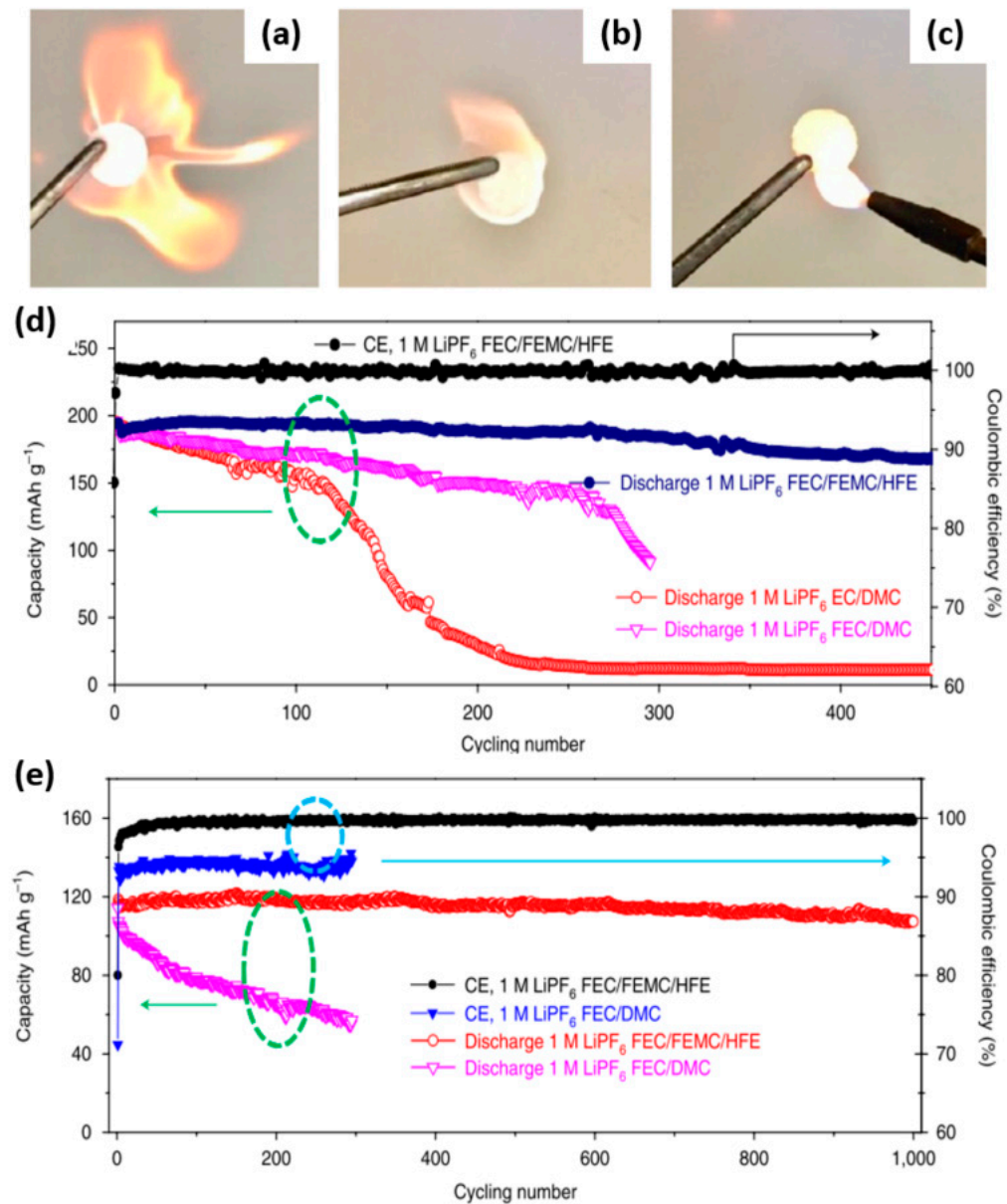

Figure 4. Flammability test for (a) $1 \mathrm{M} \mathrm{LiPF}_{6} / \mathrm{EC} / \mathrm{DMC}$, (b) $1 \mathrm{M} \mathrm{LiPF}_{6} / \mathrm{FEC} / \mathrm{DMC}$, and (c) $1 \mathrm{M}$ $\mathrm{LiPF}_{6} / \mathrm{FEC} / \mathrm{FEMC} / \mathrm{HFE}$, (d) Cycling stability at 0.5C; (e) cycling stability at 1C [26]. Reprinted with permission from Springer Nature, Nature; X. Fan, L. Chen, O. Borodin, X. Ji, J. Chen, S. Hou, T. Deng, J. Zheng, C. Yang, S. Liou, K. Amine, K. Xu, and C. Wang, Batteries with aggressive cathode chemistries, Nat. Nanotechnology, (C) 2018.

The study claimed that the $\mathrm{LiPF}_{6} \quad \mathrm{FEC} / \mathrm{FEMC} / \mathrm{HFE}$ (fluoroethylene carbonate/3,3,3fluoroethylmethyl carbonate $/ 1,1,2,2$-tetrafluoroethyl-2' $, 2^{\prime}, 2^{\prime}$-trifluoroethyl ether) electrolyte supported high-voltage cathodes of Li-metal batteries and improved Li plating/stripping, reduced dendrite formation, and increased the battery safety. Their full cells retained $93 \%$ capacity even after 1000 cycles at high voltage and a loading of $2 \mathrm{mAh} \cdot \mathrm{cm}^{-2}$, which was credited to the formation of the fluorinated interface. In a similar study, Zeng and coworkers adjusted the molar ratio of Li salt to the solvent to $\sim(1: 2)$ to obtain an improved non-flammable phosphate electrolyte with better compatibility with the graphite anode [27]. In total, 18,650 Li-ion cells with this electrolyte exhibited a safe and good cycle life and high cyclability with a Coulombic efficiency of $99.7 \%$. The electrolyte was less reactive to Li-metal electrodes; hence, good stability and a high Coulombic efficiency of $>99 \%$ was obtained for Li-metal plating and stripping in $\mathrm{Li}-\mathrm{Cu}$ half cells. The safety performance of the batteries was tested by performing short-circuiting, crushing, and nail penetration tests. Figure 5 shows the comparison between the cells using the high-molar-ratio electrolyte and the commercial carbonate electrolyte. The 1:2 ratio phosphate electrolyte passed all three tests, whereas the commercial electrolyte passed only the crush test. They also compared the flame tests of different electrolytes and, as shown in the figure, 1:2 LiTFSI + FEC + LiBOB was the most non-flammable. 
(a)

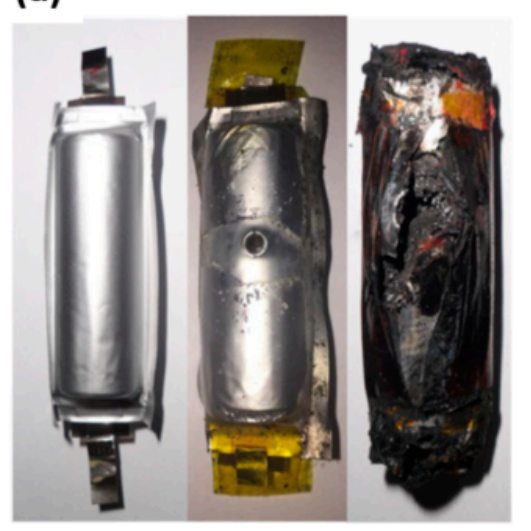

(b)

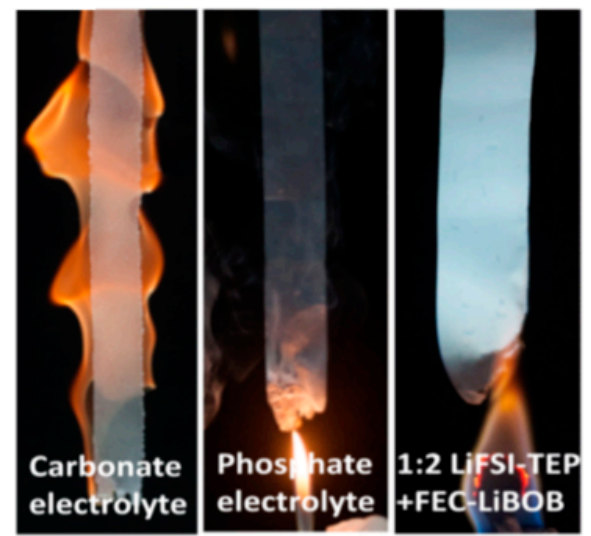

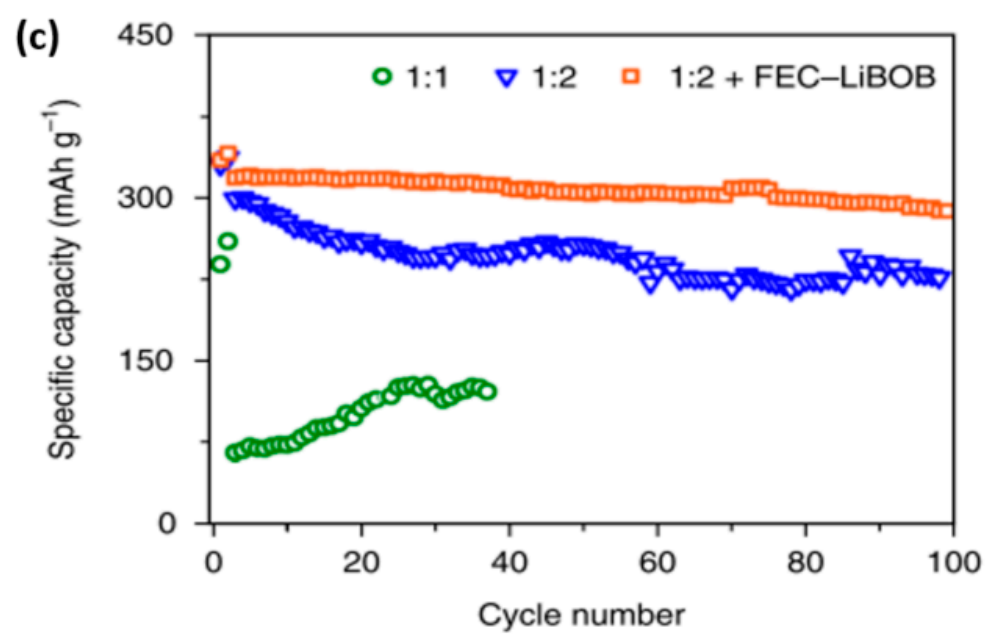

Figure 5. (a) Blank cell before nail penetration test for 18,650 cells using 1:2 LiFSI-TEP (Triethyl phosphate) + FEC-LiBOB electrolyte (middle) and commercial carbonate electrolyte (1.0 M $\left.\mathrm{LiPF}_{6} / \mathrm{EC}: \mathrm{DEC}: \mathrm{EMC}, v / v / v=1 / 1 / 1\right)$. (b) Flame tests of $1.0 \mathrm{M} \mathrm{LiPF}_{6} / \mathrm{EC}: \mathrm{DEC}: \mathrm{EMC}(v / v / v=1 / 1 / 1)$ electrolyte, 1:2 LiFSI-TEP electrolyte, and 1:2 LiFSI-TEP + FEC-LiBOB electrolyte. (c) Cycling performance at current density of $20 \mathrm{~mA} \cdot \mathrm{g}^{-1}$ with different electrolytes [27]. Reprinted with permission from Springer Nature, Nature Energy; Z. Zeng, V. Murugesan, K.S. Han, X. Jiang, Y. Cao, and L. Xiao, Non-flammable electrolytes with high salt-to-solvent ratios for Li-ion and Li-metal batteries; (c) 2018.

To overcome the risk of battery fires and explosions, Pham et al. developed a novel non-flammable electrolyte composed of $1 \mathrm{M} \mathrm{Li}$-hexafluorophosphate salt, propylene carbonate, and fluorinated linear carbonate co-solvents with high voltage stability [28]. The full batteries with the electrolyte with $1 \mathrm{wt} . \%$ FEC additive displayed high energy density, and stable cyclability performance at high voltages up to $5 \mathrm{~V}$. Figure 6 shows the comparison between the fire tests of various compositions of electrolytes. The study reported that the addition of di-(2,2,2 trifluoroethyl) carbonate (DFDEC) enabled the cathode to charge to $5.0 \mathrm{~V}$ and to deliver a significantly increased capacity of $250 \mathrm{mAh} \cdot \mathrm{g}^{-1}$ or higher. 

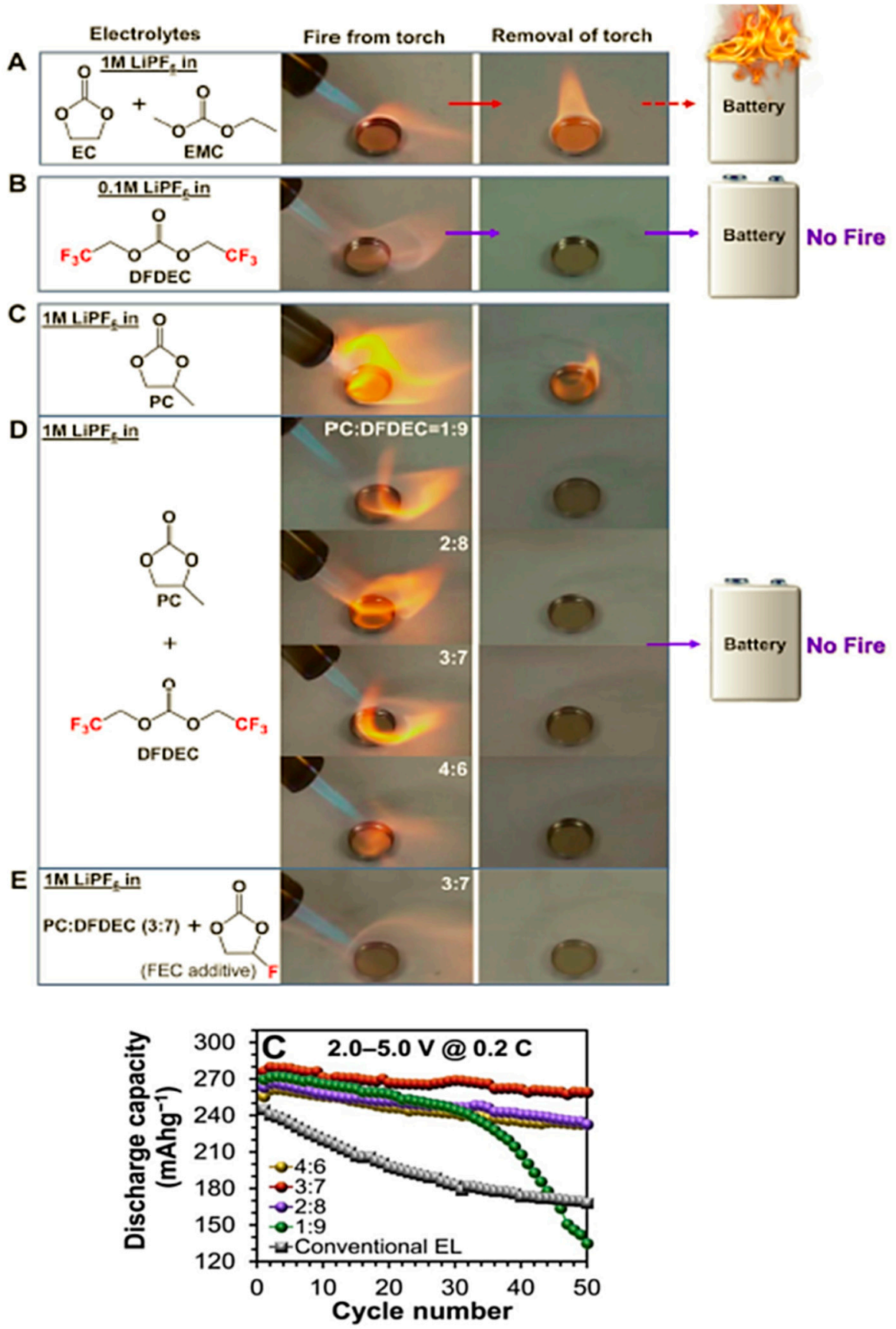

Figure 6. Fire test results for (A) conventional electrolyte of $1 \mathrm{M} \mathrm{LiPF}_{6} / \mathrm{EC}: \mathrm{EMC}$ (3:7 vol ratio), (B) $0.1 \mathrm{M} \mathrm{LiPF}_{6} /$ di-(2,2,2 trifluoroethyl) carbonate (DFDEC), (C) $1 \mathrm{M} \mathrm{LiPF}_{6} /$ propylene carbonate (PC), (D) designed electrolytes of $1 \mathrm{M} \mathrm{LiPF}_{6} / \mathrm{PC}:$ DFDEC at volume ratios of 1:9, 2:8, 3:7, and 4:6, and (E) $1 \mathrm{M}$ $\mathrm{LiPF}_{6} / \mathrm{PC}$ :DFDEC (3:7) with $1 \mathrm{wt}$.\% FEC additive. The charge-discharge cycling performance is shown below [28]. Reprinted with permission by Elsevier from Non-flammable organic liquid electrolyte for high-safety and high-energy density Li-ion batteries; H. Quang, H. Lee, E. Hwang, Y. Kwon, and S. Song, J. Power Sources, (c) 2018.

In recent years, the development of non-flammable electrolytes using trimethyl phosphate (TMP) was a topic of interest for research due to its good oxidation and poor reduction stability at the graphite anode. An electrolyte with vinylene carbonate, vinyl ethylene carbonate, and used cyclo-hexane as additives improved the battery performance [29]. A mixed electrolyte with $2 \mathrm{M} \mathrm{LiPF}_{6}$ in TMP was developed for a Li-ion battery with capacity retention of $97 \%$ at 50 cycles [30]. Li salt concentration 
was optimized, which resulted in improved battery safety. A novel non-flammable electrolyte of $\mathrm{LiPF}_{6}$ with dimethyl methyl-phosphonate (DMMP) and lithium bis-oxalatoborate (LiBOB) was reported by Dalavi's group [31]. Dimethyl methyl-phosphonate was used as a flame retardant and lithium bis-oxalatoborate was used as an anode-forming additive. The developed electrolyte exhibited improved thermal stability as compared to $\mathrm{LiPF}_{6}$ in EC/EMC without affecting the conductivity. The battery cycling performance was also significantly improved. Fluorinated alkyl phosphates (FAP) were used for safer electrolytes [32]. $\mathrm{LiPF}_{6}$ with tris(2,2,2-trifluoroethyl) phosphate (TFEP) solvent was combined with alkyl carbonates such as EC and fluoroethylene carbonate (4-fluoro-2-oxo-1,3-dioxolane, FEC). Addition of EC as a co-solvent exhibited high exothermic response at onset temperatures below $200{ }^{\circ} \mathrm{C}$, whereas FEC showed lower exothermic peaks at higher onset temperatures above $250{ }^{\circ} \mathrm{C}$; hence, they concluded that FEC is a better co-solvent for safer $\mathrm{Li}$-ion batteries for severe conditions.

Non-flammable electrolyte was obtained by Kurc via the dissolution of solid lithium bis(trifluoromethane sulphonyl) imide $\left(\mathrm{LiNTF}_{2}\right)$, lithium bis-oxalato borate ( $\left.\mathrm{LiBOB}\right)$, and lithium hexafluorophosphate $\left(\mathrm{LiPF}_{6}\right)$ in tetrahydrothiophene 1,1-dioxide or tetramethylene sulfone (TMS) with $10 \%$ vinylene carbonate (VC) [33]. They used $\mathrm{LiNiO}_{2}$ as a cathode and the $1 \mathrm{M} \mathrm{LiPF}_{6}$ in TMS $+10 \%$ VC electrolyte for the Li-ion battery and obtained 195 cycles and a Coulombic efficiency of $140 \mathrm{mAh} \cdot \mathrm{g}^{-1}$ after 20 cycles at a rate of $\mathrm{C} / 10$. TMS has good chemical and thermal stability, a low autoprotolysis constant, high polarity, low toxicity, low vapor pressure, and a high melting point of $275{ }^{\circ} \mathrm{C}$. To overcome the challenge of obtaining a poly (ethylene oxide) (PEO)-based solid electrolyte with high Li-ion conductivity and good mechanical strength, $\mathrm{Li}$ et al. synthesized a polymeric electrolyte with $40 \%$ poly-methyl hydrogen-siloxane (PMHS) and PEO [34]. The membrane exhibited an ionic conductivity of $2.0 \times 10^{-2} \mathrm{~S} \cdot \mathrm{cm}^{-1}$ at $80^{\circ} \mathrm{C}$, a high electrochemical window, and better thermal stability. The assembled $\mathrm{Li} / \mathrm{LiFePO}_{4}$ battery exhibited good stability and obtained a reversible capacity of $140 \mathrm{mAh} \cdot \mathrm{g}^{-1}$ at $60^{\circ} \mathrm{C}$ at a rate of $0.1 \mathrm{C}$. A non-flammable phosphate-based electrolyte composed of $5 \mathrm{M}$ L1 (M) Li bis(fluorosulfonyl) imide (LiFSI) in a trimethyl phosphate (TMP) solvent was developed Shi et al. [35]. Figure 7 depicts that the electrolyte with $1 \mathrm{M} \mathrm{LiPF6/ethylene}$ carbonate (EC) + diethyl carbonate (DEC) ignited immediately and continued to burn, whereas the $5 \mathrm{M}$ LiFSI/TMP electrolyte was non-flammable. Four hundred cycles were obtained when the electrolyte was used in $\mathrm{Li} \mid \mathrm{LiFePO}_{4}$ cells.

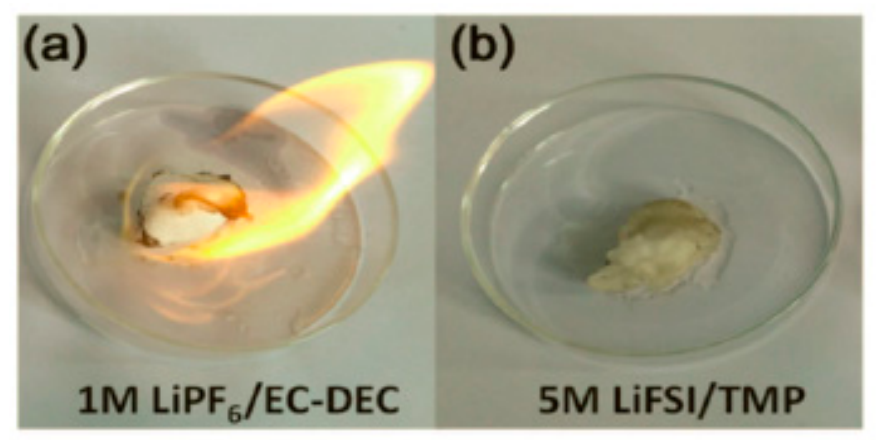

Figure 7. (a) Flammability tests of $1 \mathrm{M} \mathrm{LiPF}_{6} / \mathrm{EC}-\mathrm{DEC}$ and (b) $5 \mathrm{M}$ LiTFSi/TMP electrolyte [35]. Reprinted with permission, (c) 2018.

Janssen et al. synthesized 1,3-dimethylimidazolidin-2-mm-trifluoroborate ( $\mathrm{NHC}^{\left.-\mathrm{BF}_{3}\right)}$ and 1,3-dimethylimidazolidin-2-mm-tetrafluorotrifluoromethylphosphate $\left(\mathrm{NHC}-\mathrm{PF}_{4} \mathrm{CF}_{3}\right)$ on $\mathrm{LiNi}_{1 / 3} \mathrm{Co}_{1 / 3} \mathrm{Mn}_{1 / 3} \mathrm{O}_{2}$ (NMC111) electrodes of Li-ion batteries as overcharge protection shutdown additives in $1 \mathrm{M} \mathrm{LiPF}_{6}$ in EC:DEC $(w / w=3 / 7)$ electrolyte [36]. 


\subsection{Gel Polymer Electrolytes}

Gel polymer electrolytes (GPE) are made by combining different types of salts such as $\mathrm{LiPF}_{6}$ and $\mathrm{LiBF}_{4}$ in aprotic solvents like PC, EC:DEC, and EC:DMC, prepared by ultraviolet (UV) polymerization. They have characteristics of both solid and liquid electrolytes. Various GPEs with different compositions were developed for different battery chemistries [37-40]. In this section, we discuss the polymer electrolytes that were fabricated for safer Li-ion batteries. Free-standing gel polymer electrolytes (GPE) with polymeric ionic liquid, poly[diallyldimethylammonium] bis(trifluoromethane) sulfonimide, 1-ethyl-3-methylimidazolium bis (trifluoromethane) sulfonimide, and lithium salt were developed by Meer et al. [15], and were found to be thermally stable. The electrolyte contained $80 \mathrm{wt} . \%$ ionic liquid and lithium salt content, which resulted in highly ionically conductive electrolyte films. Galvanostatic charge/discharge cycling of $\mathrm{Li} / \mathrm{GPE} / \mathrm{LiFePO}_{4}$ batteries exhibited a discharge capacity of $169.3 \mathrm{mAh} \cdot \mathrm{g}^{-1}$ at $\mathrm{C} / 10$ and $126.8 \mathrm{mAh} \cdot \mathrm{g}^{-1}$ at $1 \mathrm{C}$. The capacity retention capability at a rate of $5 \mathrm{C}$ was up to 40 cycles at $22{ }^{\circ} \mathrm{C}$. Figure 8 shows the free-standing GPE.

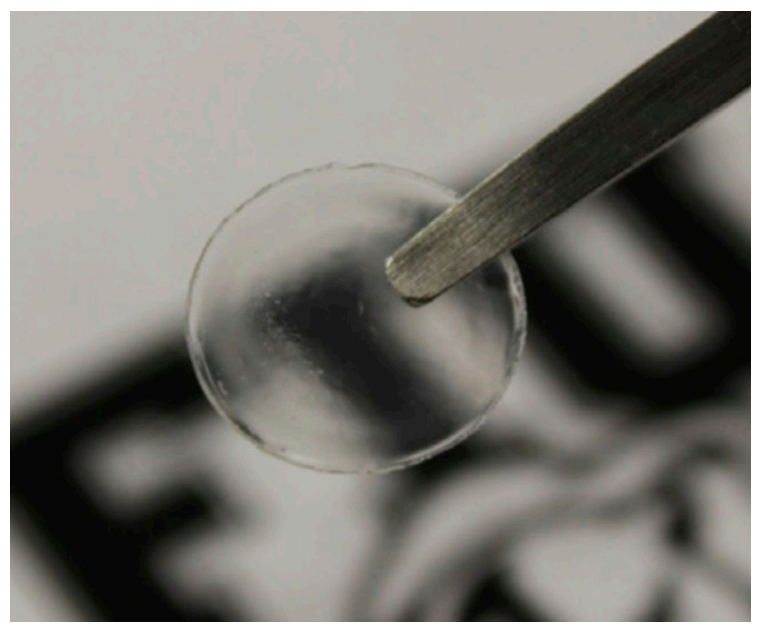

Figure 8. Gel polymer electrolyte (GPE) demonstrating its free-standing property [15]. Reprinted with permission by Elsevier from Electrochimica Acta, 213, Meer Safa, Amir Chamaani, Neha Chawla, and Bilal El-Zahab, Polymeric Ionic Liquid Gel Electrolyte for Room Temperature Lithium Battery Applications, 587-593, (c) 2016.

A gel polymer electrolyte (GPE) based on electro-spun polyvinylidene fluoride (PVDF)/halloysite nanotube (HNT) nanocomposite non-wovens was synthesized and used as a separator for Li-ion batteries [41]. The GPE as a separator exhibited minimal thermal shrinkage and higher melting temperature which was proven to be important for obtaining a safer Li-ion battery. A good tensile and puncture strength as compared with a commercially available separator was observed. The developed $\mathrm{Li} / \mathrm{GPE} / \mathrm{LiCoO}_{2}$ battery obtained a capacity of $138.01 \mathrm{mAh} \cdot \mathrm{g}^{-1}$ with $97 \%$ Coulombic efficiency. The batteries even displayed better cyclability.

A nano-particle-decorated poly(methyl methacrylate-acrylonitrile-ethyl acrylate) (P(MMAAN-EA))-based gel polymer electrolyte (GPE) was formulated using 1-ethyl-3-methylimidazolium bis(trifluoromethanesolfonyl) imide (EMITFSI) ionic liquid as a plasticizer by $\mathrm{Li}$ et al. [13]. The membrane exhibited a high porosity of $70 \%$, an ionic conductivity of $3.2 \times 10^{-3} \mathrm{~S} \cdot \mathrm{cm}^{-1}$ at ambient temperature with better anti-thermal shrinkage and flame retardation performance, and a fracture strength of $160 \mathrm{MPa}$. The batteries fabricated with the membrane retained $~ 95 \%$ capacity after 100 cycles under $0.2 \mathrm{C}$ at room temperature. Figure 9 shows the flame test of the membrane soaked with commercially carbonated organic electrolyte and the ionic liquid. 

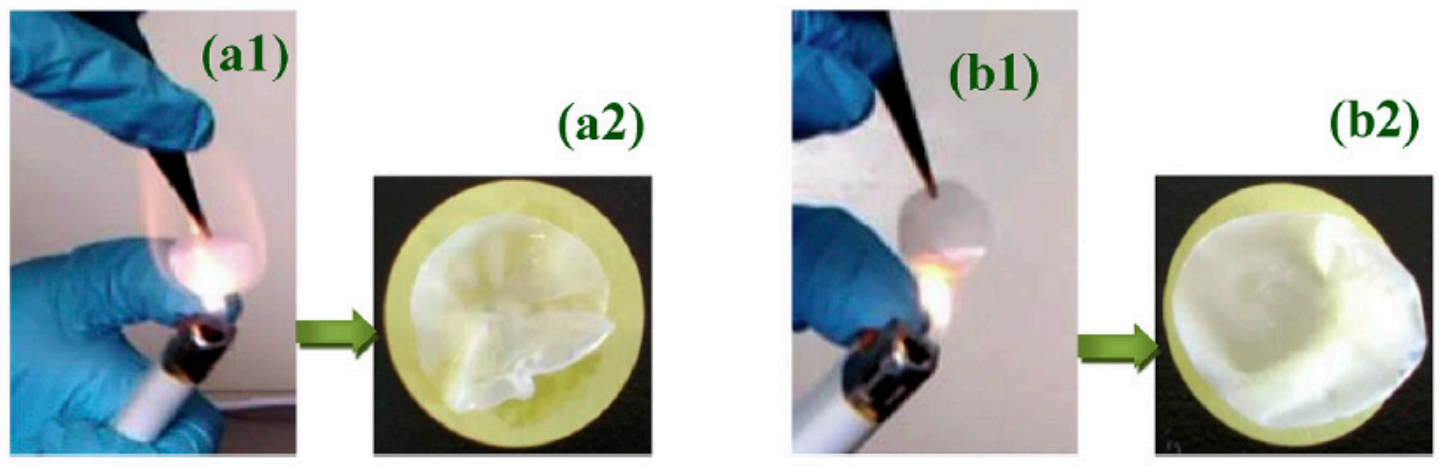

Figure 9. Combustion test of the MS5 $\left(\mathrm{SiO}_{2}: \mathrm{Al}_{2} \mathrm{O}_{3}=5: 5\right)$ membrane immersed in commercial carbonated organic liquid electrolyte before (a1), and after (a2) the burning test; and the combustion test of the membrane immersed in the ionic liquid electrolyte before (b1), and after (b2) the burning test [13]. Reprinted with permission by Elsevier from Application of the imidazolium ionic liquid based nano-particle decorated gel polymer electrolyte for high safety lithium ion battery; M. Li, Y. Liao, Q. Liu, J. Xu, P. Sun, and H. Shi; Electrochimica Acta, 284 188-201, (c) 2018.

A gel polymer electrolyte containing succinonitrile (GPE-SN) was designed using the immersion method by Pengfei Lv, represented as GPE-SN-IM. GPE-SN-IM exhibited an ionic conductivity of $1.63 \times 10^{-3} \mathrm{~S} \cdot \mathrm{cm}^{-1}$ at $25{ }^{\circ} \mathrm{C}$ [42]. It obtained a tensile strength of $6.5 \mathrm{MPa} . \mathrm{A} \mathrm{LiCoO} 2 / \mathrm{Li}_{4} \mathrm{Ti}_{5} \mathrm{O}_{12}$ film battery with a high-mechanical-strength GPE-SN-IM film displayed a good cyclability of 100 cycles. These batteries showed good cyclability even at elevated temperatures up to $55{ }^{\circ} \mathrm{C}$ due to better thermal stability. Figure 10 shows the flammability tests of GPE-LE with EC/DMC and GPE-SN-IM, proving that GPE-SN-IM is a much safer electrolyte for Li-ion batteries.
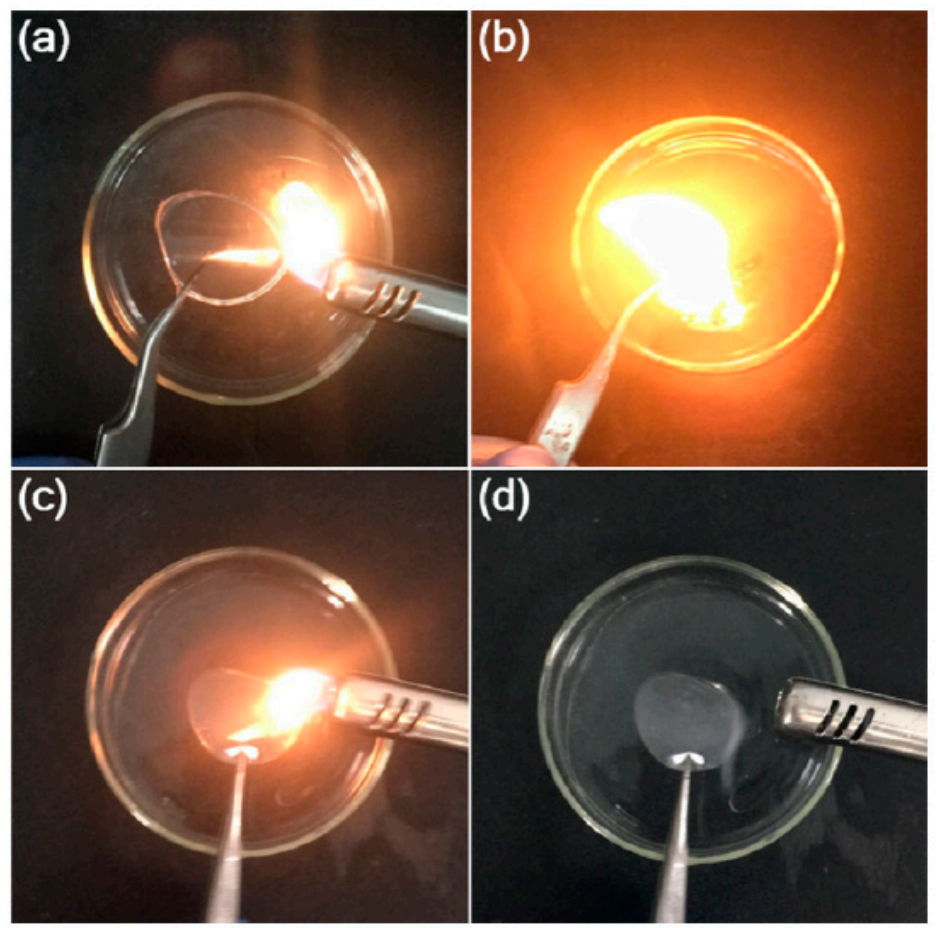

Figure 10. Flame ignition tests for (a) GPE-LE and (c) GPE-SN-IM. After contacting the flame, (b) GPE-LE quickly burns, but (d) GPE-SNIM does not burn [42]. Reprinted with permission by the American Chemical Society from Robust Succinonitrile-Based Gel Polymer Electrolyte for Lithium-Ion Batteries Withstanding Mechanical Folding and High Temperature; P. Lv, Y. Li, Y. Wu, G. Liu, H. Liu, S. Li, C. Tang, J. Mei, and Y. Li; @ 2018. 
Polyacrylonitrile (PAN)/poly(vinyl alcohol) (PVA) blending membrane-based gel polymer electrolytes with PVA/PAN ratios of 0:100, 10:90, 20:80, and 40:60 were developed, denoted as BM-0, BM-1, BM-2, and BM-3, respectively [43]. The cell test revealed capacity retentions of $58 \%, 1 \%$, $94 \%, 96 \%$, and $40 \%$ for the Celgard 2320 separator, BM-0, BM-1, BM-2, and BM-3, respectively, after 200 cycles at a rate of $1 \mathrm{C}$. Figure 11 shows the images of the membranes heated from $25^{\circ} \mathrm{C}$ to $100{ }^{\circ} \mathrm{C}$ to $160{ }^{\circ} \mathrm{C}$. Celgard 2320 shrinked severely at $160^{\circ} \mathrm{C}$, while BM-0, BM-1, BM-2, and BM-3 showed a negligible dimensional change due to the PAN membrane, which possesses a melting temperature of more than $300{ }^{\circ} \mathrm{C}$.

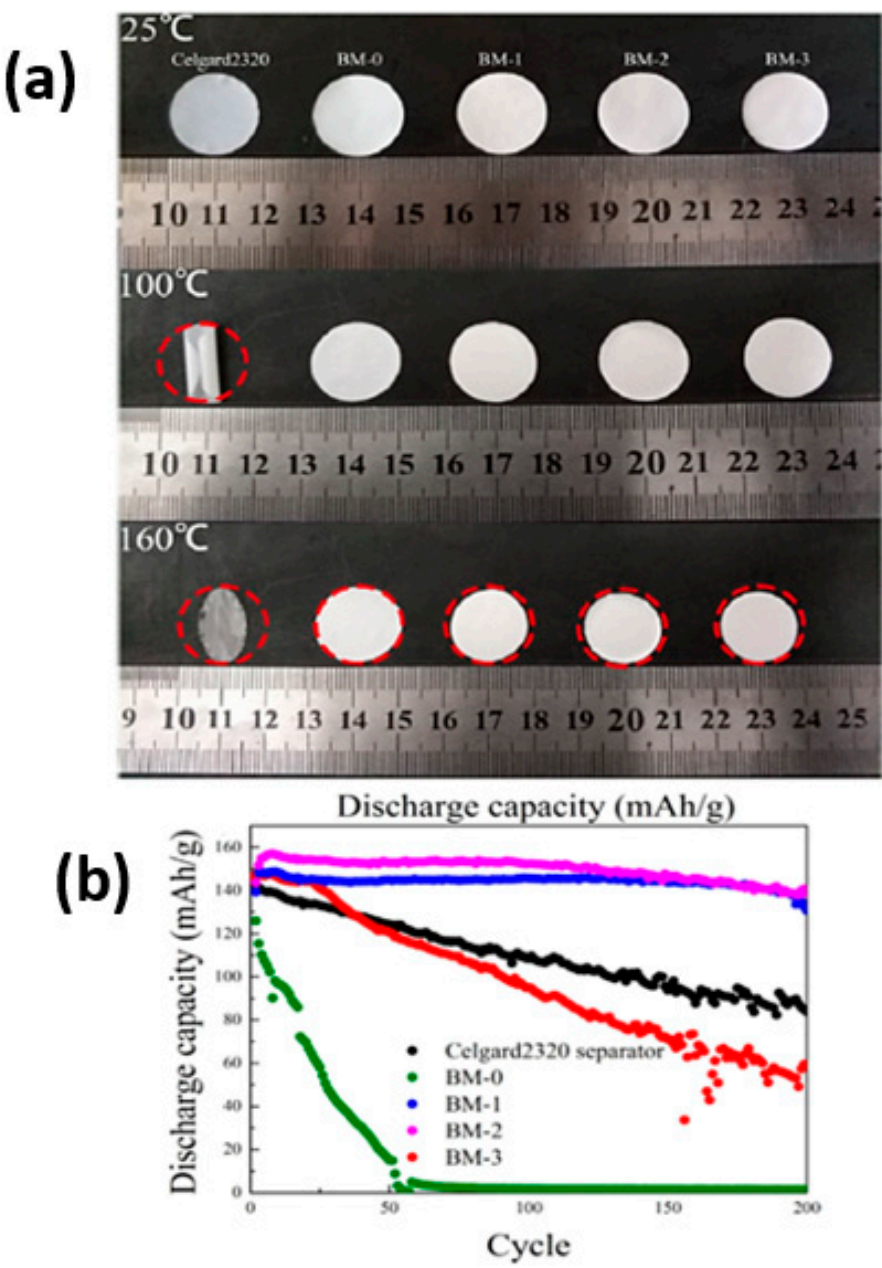

Figure 11. (a) Photographs of the membranes before and after heat treatment in an oven at $25{ }^{\circ} \mathrm{C}$, $100{ }^{\circ} \mathrm{C}$, and $160{ }^{\circ} \mathrm{C}$. (b) The cycling stability of the cells at $1 \mathrm{C}$ [43]. Reprinted with permission by Elsevier from Blending-based polyacrylonitrile/poly (vinyl alcohol) membrane for rechargeable lithium ion batteries; C. He, J. Liu, J. Li, F. Zhu, and H. Zhao, J. Memb. Sci.; 560; (c) 2018.

In situ thermally induced free-radical polymerization was used to develop a GPE (gel polymer electrolyte) with an interpenetrating polymer network (IPN-GPE) [44]. The IPN-GPE with cross-linked structure exhibited high flexibility and deformability, and a thermal stability of over $310^{\circ} \mathrm{C}$. It displayed a good electrochemical stability window and an ionic conductivity of $1.3 \times 10^{-3} \mathrm{~S} \cdot \mathrm{cm}^{-1}$ at $30^{\circ} \mathrm{C}$. The rechargeable batteries with the gel electrolyte displayed good electrical performance, safety, cyclability, and rate capability. Combustion tests were performed on conventional carbonate-based, $1 \mathrm{M} \mathrm{LiPF}_{6}$ in EC/DMC/DEC $(v / v / v=1 / 1 / 1)$ liquid electrolyte and IPN-GPE, as depicted in Figure 12. The low flammability of IPN-GPE makes it a safer electrolyte for Li-ion batteries. 

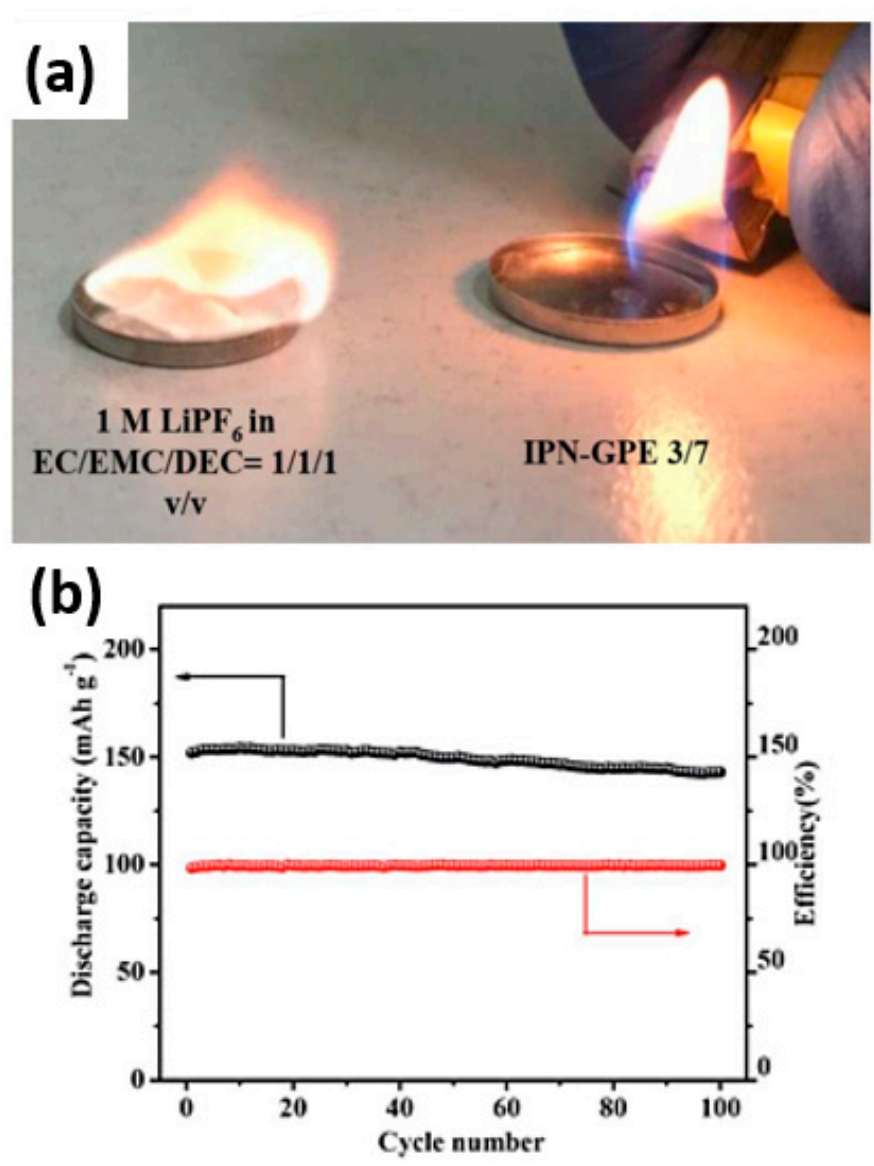

Figure 12. (a) Combustion testing of $1 \mathrm{M} \mathrm{LiPF}_{6} \mathrm{EC} / \mathrm{EMC} / \mathrm{DEC}$ liquid electrolyte and IPN-GPE (Gel polymer electrolyte with interpenetrating polymer network). (b) The cycling performance of the cell at 0.1C [44]. Reproduced from Reference [44] with permission from the Royal Society of Chemistry.

The effect of adding fluoroethylene carbonate (FEC) as an electrolyte additive for ethyl-methyl sulfone (EMS) electrolytes with $\mathrm{LiPF}_{6}$ as a conducting salt in graphite based batteries was studied, and it was concluded that lowering the EC led to a lower conductivity of the electrolyte, whereas increasing EC enhanced flammability [45]. Wang et al. developed and studied a star-comb co-polymer based on poly(D,L-lactide) (PDLLA) macromonomer and poly(ethylene glycol)methyl ether methacrylate (PEGMA) for Li-ion batteries [46]. For synthesis of the six-arm vinyl-functionalized PDLLA macromonomer, a ring-opening polymerization (ROP) of D,L-lactide and an acylation of the hydroxy end-groups were used. The prepared solid polymer electrolyte exhibited good thermal stability and electrochemical properties. A gel electrolyte consisting of a fluoropolymer/cellulose derivative matrix and liquid electrolyte was fabricated with reversible thixotropic transformation and abuse tolerance [47]. The electrolyte displayed high ionic conductivity and low crystallinity. Flexible composite ionic liquid gel polymer electrolytes (ILGPEs) supported by $\mathrm{Li}_{1.5} \mathrm{Al}_{0.5} \mathrm{Ge}_{1.5}\left(\mathrm{PO}_{4}\right)_{3}$ (LAGP) were fabricated and investigated by Guo et al. for improving the electrochemical performance and thermal safety of the batteries [48]. They optimized 10\% LAGP for the electrolyte. LAGP particles reduced the crystallinity of the polymer matrix, thus providing lithium ions, which resulted in elevated ionic conductivity and Li-ion transference number. The cycling stability of $\mathrm{LiFePO}_{4} / 10 \% \mathrm{LAGP} / \mathrm{Li}$ batteries was improved since no dendrite was formed on the lithium anode. Figure 13 shows the flammability tests and the cycling performance of the batteries. 

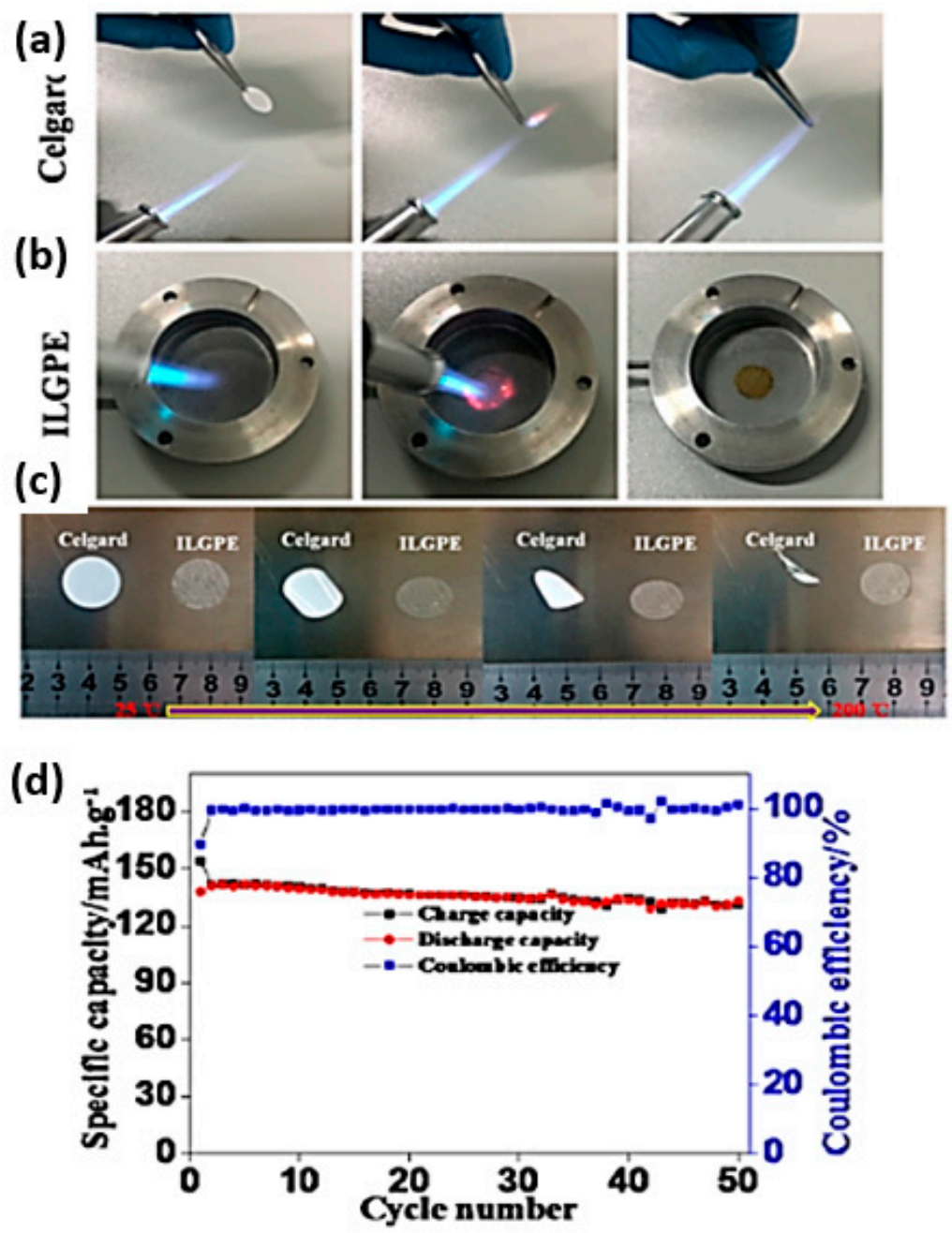

Figure 13. $(\mathbf{a}-\mathbf{c})$ : Flammability tests of commercial Celgard membrane and ILGPE/10\%LAGP (ionic liquid gel polymer electrolytes $\left./ 10 \% \mathrm{Li}_{1.5} \mathrm{Al}_{0.5} \mathrm{Ge}_{1.5}\left(\mathrm{PO}_{4}\right)_{3}\right)$. (d) The cycling performance of $\mathrm{LiFePO}_{4} /$ ILGPE/10\%LAGP/Li. Reproduced from Reference [48] with permission, (c) 2018.

Fu et al. developed a bendable, flexible polymer electrolyte membrane (PEM) based on cross-linkable polyurethane precursor, polyethylene glycolbiscarbamate dimethacrylate (PEGBCDMA), that was thermally stable and flame retardant [49]. The lithium iron phosphate $\left(\mathrm{LiFePO}_{4}\right) / \mathrm{PEM} /$ graphite full battery with the PEM exhibited approximately $80 \%$ specific capacity retention up to 250 cycles. A cross-linking polymer network of poly(acrylic anhydride-2-methyl-acrylic acid-2-oxirane-ethyl ester-methyl methacrylate) (PAMM)-based electrolyte was developed as an electrolyte material for lithium-ion batteries by Ma et al. [50]. The $\mathrm{LiNi}_{0.5} \mathrm{Mn}_{1.5} \mathrm{O}_{4} / \mathrm{Li}$ and $\mathrm{LiNi}_{0.5} \mathrm{Mn}_{1.5} \mathrm{O}_{4} / \mathrm{Li}_{4} \mathrm{Ti}_{5} \mathrm{O}_{12}$ batteries with PAMM-based gel polymer electrolyte delivered stable charging/discharging profiles and excellent rate performance at room temperature and even at $55^{\circ} \mathrm{C}$. A capacity of $128 \mathrm{mAh} \cdot \mathrm{g}^{-1}$ and a significantly improved Coulombic efficiency of $96 \%$ at $0.1 \mathrm{C}$ after 100 cycles for $\mathrm{LiNi}_{0.5} \mathrm{Mn}_{1.5} \mathrm{O}_{4} / \mathrm{Li}_{4} \mathrm{Ti}_{5} \mathrm{O}_{12}$ was achieved, as shown in Figure 14. 


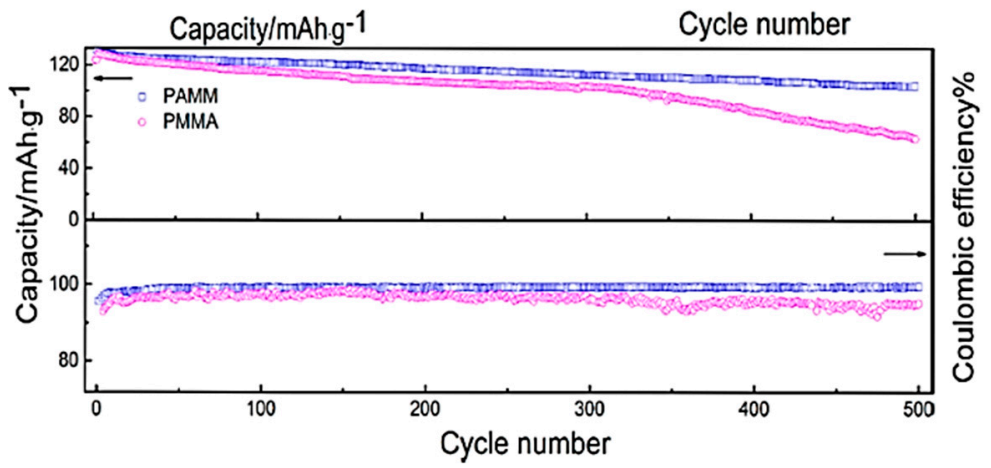

Figure 14. Discharge capacity and Coulombic efficiency of $\mathrm{LiNi}_{0.5} \mathrm{Mn}_{1.5} \mathrm{O}_{4} / \mathrm{Li}$ cells using PAMM (poly(acrylic anhydride-2-methyl-acrylic acid-2-oxirane-ethyl ester-methyl methacrylate)) and PMMA (poly(methyl methacrylate-acrylonitrile) at 0.1C [50]

A flexible, flame-retardant solid polymer electrolyte, combining PCL/SN (Poly( $\varepsilon$-caprolactone)/ Succinonitrile) blends with a polyacrylonitrile (PAN)-skeleton and forming hierarchical architectures, was developed by Zhang et al. [51]. Kim et al. used $\mathrm{Mg}(\mathrm{OH})_{2}$, a flame-retardant material, for their composite polymer electrolyte (CPE) [52]. They did a comparative study by varying the amount of $\mathrm{Mg}(\mathrm{OH})_{2}$ added to the electrolyte. Figure 15 shows the flammability tests at different wt.\% additive in the electrolyte. As can also be seen from Figure 15, the composite gel polymer electrolyte with $40 \mathrm{wt} . \%$ $\mathrm{Mg}(\mathrm{OH})_{2}$ displayed a higher discharge capacity at $2 \mathrm{C} / 2 \mathrm{C}$ charging/discharging current after 200 cycles, as compared to $20 \mathrm{wt} . \%$ or $0 \mathrm{wt} . \%$.

(a)

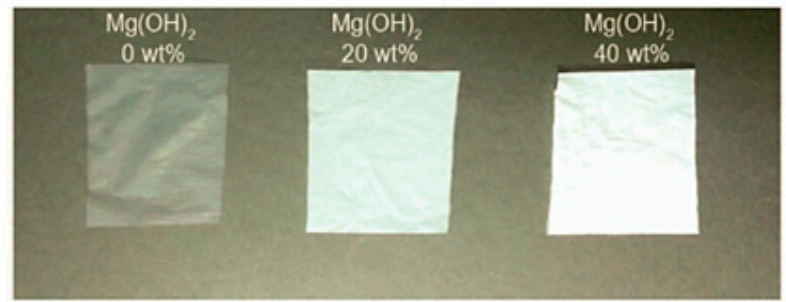

(b)

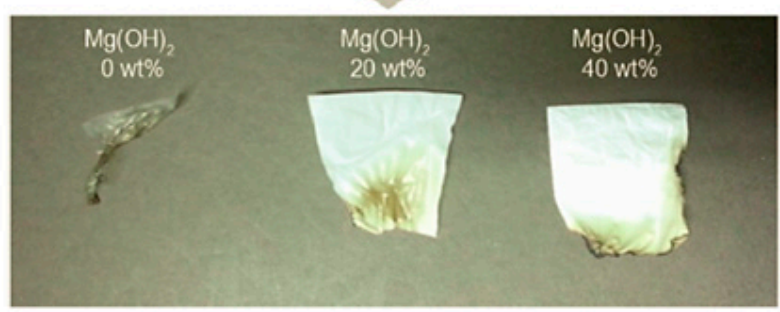

(c)

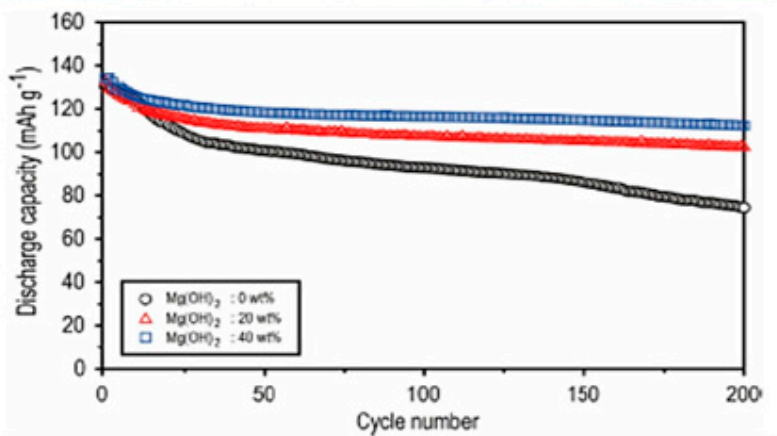

Figure 15. (a,b) Flame-retardant tests of composite gel polymer films with different amounts of $\mathrm{Mg}(\mathrm{OH})_{2}$. (c) The cycle performance of cells with composite gel polymer electrolytes with different concentrations of $\mathrm{Mg}(\mathrm{OH})_{2}$ at 2C rate [52]. Reprinted with permission, (c) 2018. 
An ionogel electrolyte was fabricated by Chen et al. by immobilizing ionic liquids within a nano-porous zirconia-supported matrix (represented as ZIE) which provided the properties of both solid and liquid electrolyte ionic transport, thus improving the thermal stability and safety [53]. The assemble battery exhibited excellent cyclability and a discharge capacity of $\sim 136 \mathrm{mAh} \cdot \mathrm{g}^{-1}$ after 200 cycles at $30{ }^{\circ} \mathrm{C}$. The battery had a wide operating temperature range from $-10{ }^{\circ} \mathrm{C}$ to $90{ }^{\circ} \mathrm{C}$. Figure 16 shows the burning test performed on the ZIE to demonstrate the safety feature. It confirmed the high heat-resistant ability of the electrolyte.
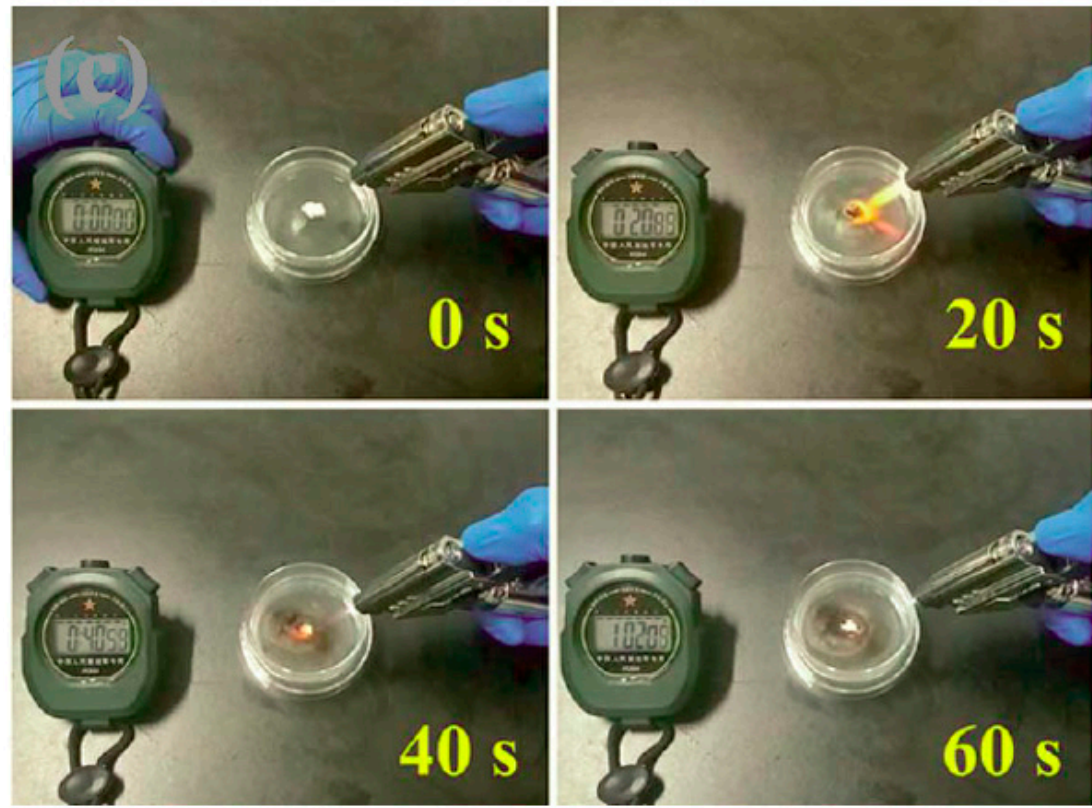

Figure 16. Flammability test of the ZIE using a flame gun [53]. Reproduced from Reference [35] with permission from the Royal Society of Chemistry.

Tetra PEG gel mixed with 1.0 M LiPF 6 in an EC + DEC + TFEP mixture $(v / v / v=53 / 27 / 20)$ electrolyte for Li-ion batteries was developed by Han et al. [54]. The resulting Tetra PEG gel electrolyte was used with a $\mathrm{LiFePO}_{4}$ cathode in Li-ion batteries. $\mathrm{Li}$ et al. developed a Li-ion battery using an interpenetrating rigid flexible poly (aryl ether ketone) non-wovens (PAEKNW) cross-linked with a poly(ethylene glycol) dimethacrylate electrolyte, $\mathrm{LiFePO}_{4}$ cathode, and $\mathrm{Li}$ metal anode [55]. The cross-linked electrolyte exhibited good flame-retarding abilities. Jia et al. chemically bonded phosphonate with the gel polymer electrolyte to obtain a flame-resistive electrolyte for a safe Li-ion battery [56].

\subsection{Additives for Electrolytes}

Using additives in electrolytes is a proven method to enhance the performance of the battery. Liu et al. used different concentrations of methyl diethyl phospho-noacetate (MDPCT), triethyl-2-fluoro-2-phosphonoacetate (TFPCT) and carbethoxy ethylidene triphenylphosphorane (CETPE) flame-retardant additives into the blank electrolytes to improve the thermal stability of the electrolyte and reduce the flammability [57]. They found $5 \mathrm{wt} . \%$ additive to be the optimum for the most flame-retardant effect. According to the electrochemical tests, the addition of $5 \mathrm{wt} . \%$ TFPCT enhanced the discharge capacity of the NCA $\left(\mathrm{LiNi}_{0.8} \mathrm{Co}_{0.15} \mathrm{Al}_{0.05} \mathrm{O}_{2}\right) / \mathrm{Li}$ half-cell, which exhibited a capacity retention as high as $92.2 \%$ at a current density of $0.5 \mathrm{C}$ after 100 cycles. Figure 17 shows the flammability tests of the various electrolytes. 

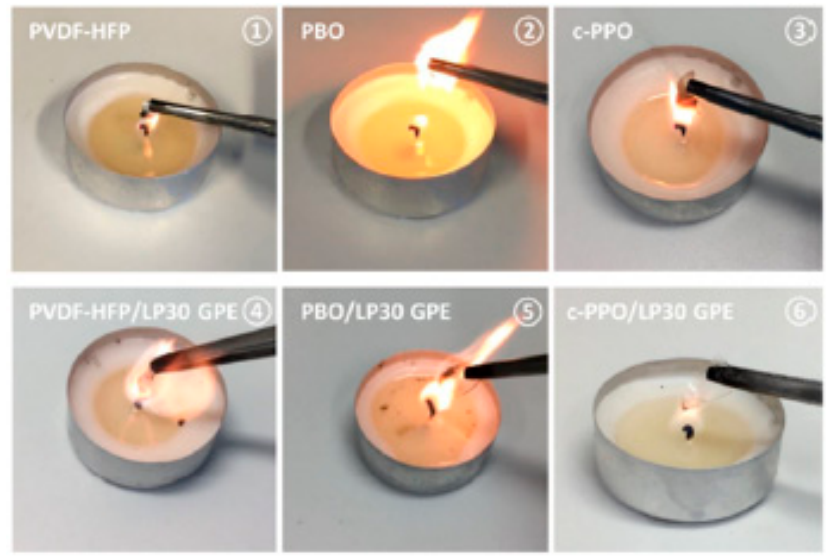

Figure 17. Flammability measurement of PVDF-HFP (polyvinylidenefluoride-hex- afluoropropylene), PBO (poly [benzyl methacrylate-co-oligo(ethylene glycol)ether methacrylate]), and c-PPO (cross-linked poly[dimethyl-p-vinyl benzyl phosphonate-co-oligo (ethylene glycol) meth acrylate] co-polymer) polymer matrices and their corresponding GPEs.

The addition of $0.5 \%$ of diethyl(thiophen-2-ylmethyl) phosphonate (DTYP) additive to the base electrolyte aided in improving the capacity retention of a high-voltage $\mathrm{Li}$-ion cell using $\mathrm{LiNi}_{0.5} \mathrm{Mn}_{1.5} \mathrm{O}_{4}$ from $18 \%$ to $85 \%$ after 280 cycles at $1 \mathrm{C}$ at $60{ }^{\circ} \mathrm{C}$. The novel electrolyte also aided in reducing the self-extinguishing time of the electrolyte from $88 \mathrm{~s}$ to $77 \mathrm{~s}$ [58]. Figure 18 shows the flammability tests and the cycling performance of the batteries with and without DTYP electrolyte.
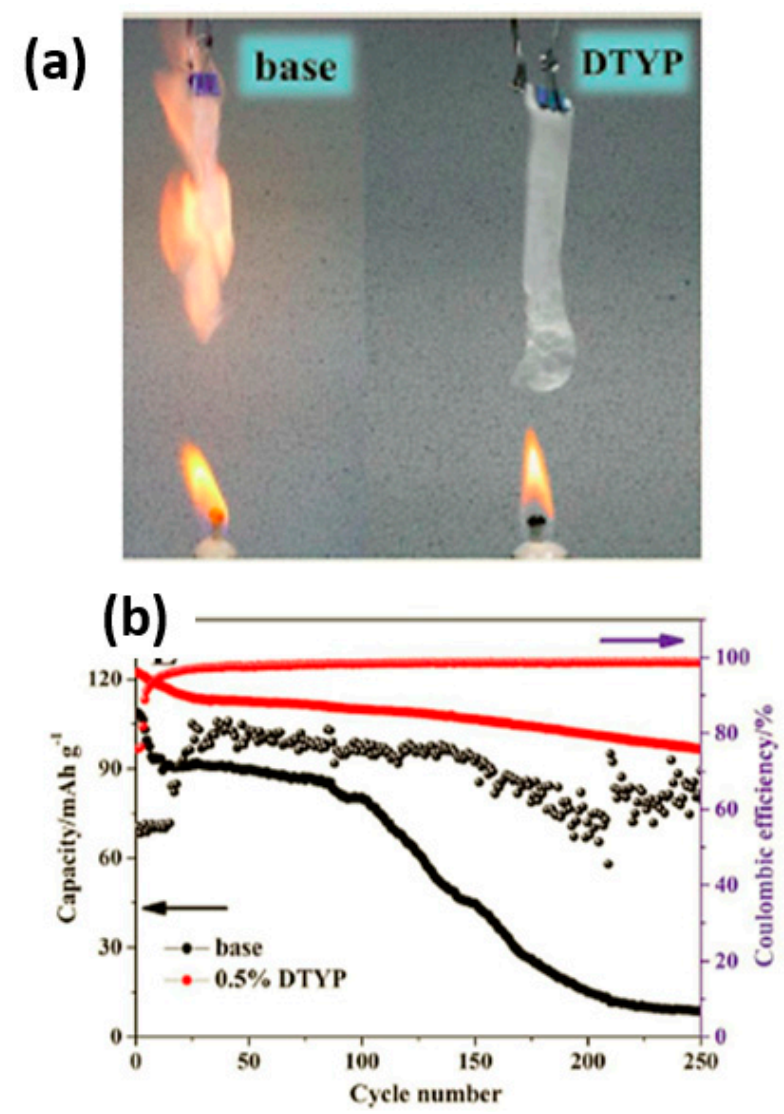

Figure 18. (a) Flammability tests of the PE membrane with base and DTYP-containing electrolytes. (b) The cycling performance of the batteries with the base and DTYP-containing electrolytes [58]. Reprinted with permission, (c) 2018. 
Sheng et al. improved the ionic conductivity of solid-state electrolytes via an interaction between $\mathrm{Mg}_{2} \mathrm{~B}_{2} \mathrm{O}_{5}$ nanowires and $\mathrm{SO}_{2}{ }^{-}$in the $\mathrm{TFSi}^{-}$anion [59]. The $\mathrm{Mg}_{2} \mathrm{~B}_{2} \mathrm{O}_{5}$ nanowire additive has high strength and is a good flame retardant. The cycling performance of the solid-state Li-ion batteries with poly (ethylene oxide)/LiTFSi $/ \mathrm{Mg}_{2} \mathrm{~B}_{2} \mathrm{O}_{5}$ electrolyte at $1.0 \mathrm{C}$ and $50{ }^{\circ} \mathrm{C}$ is shown in Figure 19 . A stable specific capacity of approximately $120 \mathrm{mAh} \cdot \mathrm{g}^{-1}$ in 230 discharge-charge cycles was achieved.

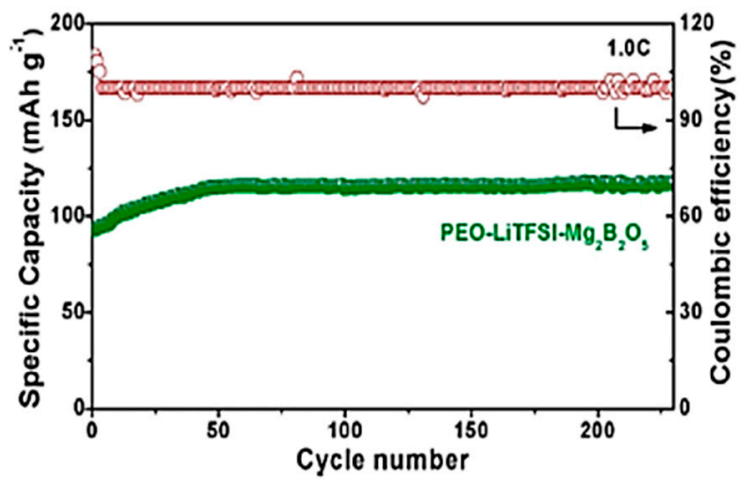

Figure 19. Cycling performance of $\mathrm{LiFePO}_{4} / \mathrm{Li}$ solid-state $\mathrm{Li}$-ion batteries with poly(ethylene oxide)/LiTFSi $/ 10 \% \mathrm{Mg}_{2} \mathrm{~B}_{2} \mathrm{O}_{5}$ at $50{ }^{\circ} \mathrm{C}$ [59], (C) 2018.

An electrolyte additive of a fluorinated phosphazene derivative, ethoxy-(pentafluoro)cyclotriphosphazene (PFN), that significantly improved the battery performance of lithium nickel manganese oxide $\left(\mathrm{LiNi}_{0.5} \mathrm{Mn}_{1.5} \mathrm{O}_{4}\right)$ cathode batteries was fabricated by Liu et al. [60]. Figure 20 shows the flammability tests comparing the PFN electrolyte with $\mathrm{LiPF}_{6}$ and the cycling performance of a $\mathrm{LiNi}_{0.5} \mathrm{Mn}_{1.5} \mathrm{O}_{4} /$ graphite full cell with or without $5 \mathrm{wt}$.\% PFN-containing electrolyte at $1 \mathrm{C}$.

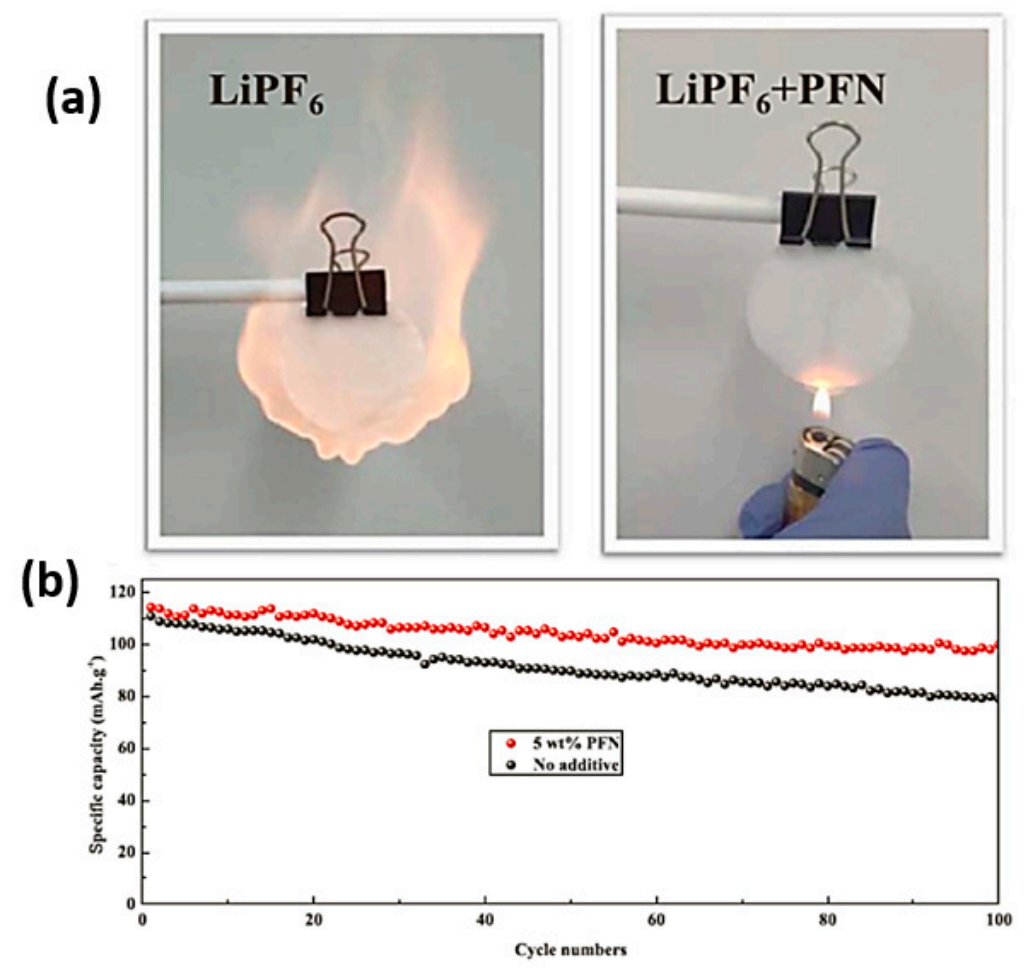

Figure 20. (a) Flammability tests of base electrolyte $1 \mathrm{M} \mathrm{LiPF}_{6} / \mathrm{EC}+\mathrm{DEC}+\mathrm{DMC}(v / v / v$ $=1 / 1 / 1$ ) and (b) the same electrolyte with 5 wt. $\%$ PFN (Fluorinated phosphazene derivative, ethoxy-(pentafluoro)-cyclotriphosphazene) additive. (c) The cycling performance of the batteries with and without the electrolyte, and with additive is shown below [60]. Reprinted with permission, (C) 2018. 
A new flame-retardant electrolyte additive ethoxy(pentafluoro)cyclotriphosphazene (PFPN) was developed by $\mathrm{Li}$ et al., with $5 \%$ additive to the electrolyte achieving better flame-retardant properties [61]. The initial discharge capacity of the Li-ion batteries with $\mathrm{LiCoO}_{2}$ cathode and $5 \%$ PFPN was $150.7 \mathrm{mAh} \cdot \mathrm{g}^{-1}$, with a capacity retention of $99.14 \%$ after 30 cycles at $0.1 \mathrm{C}$. A poly(bis-(ethoxyethoxyethoxy)phosphazene) (EEEP) electrolyte additive with an electro-oxidable $\mathrm{P}-\mathrm{O}$ bond was developed by Zhou et al. [62] to enhance the cycling performance of $\mathrm{LiCoO}_{2}$ cathodes under high-voltage operations. The $5 \mathrm{wt} . \%$ EEEP in electrolyte aided in reducing the flammability and also increasing the cyclability of the battery by forming a protective layer on the cathode surface that prevented electrolyte decomposition.

There were few researches on water-in-salt electrolytes for replacing the traditional organic electrolytes in Li-ion batteries to improve the safety and stability of the batteries at a lower cost. Sun et al. demonstrated the use of "water-in-salt" electrolyte $\left(21 \mathrm{M}\right.$ LiTFSI in $\left.\mathrm{H}_{2} \mathrm{O}\right)$ with a TiS ${ }_{2}$ anode, which displayed high electrochemical reversibility when paired with a $\mathrm{LiMn}_{2} \mathrm{O}_{4}$ cathode [63].

Table 1 summarizes the different non-flammable electrolytes and their electrochemical performance for Li-ion batteries.

Table 1. Summary of non-flammable electrolytes and their electrochemical performance.

\begin{tabular}{|c|c|c|c|c|c|c|}
\hline Electrolyte Composition & $\begin{array}{c}\text { Cathode/Battery } \\
\text { Type }\end{array}$ & $\begin{array}{l}\text { Discharge } \\
\text { Capacity } \\
\left(\mathrm{mAh} \cdot \mathrm{g}^{-1}\right)\end{array}$ & $\begin{array}{l}\text { Number of } \\
\text { Cycles }\end{array}$ & $\begin{array}{l}\text { Capacity } \\
\text { Retention }\end{array}$ & Rate & Reference \\
\hline $\begin{array}{c}1 \mathrm{M} \mathrm{LiPF}_{6} \text { in } \mathrm{EC} / \mathrm{DFSM}_{2} / \mathrm{EMC} \\
(2 / 3 / 5 \text { in vol. })+5 \mathrm{wt} \% \text { FEC }\end{array}$ & $\begin{array}{l}\mathrm{LiCoO}_{2}(\mathrm{LCO}) / \\
\text { graphite full cell }\end{array}$ & & 135 & $92 \%$ & & [11] \\
\hline $\begin{array}{c}\text { SN1IL/DMC }(v / v=1 / 1) \\
\text { doped with } 0.6 \mathrm{M} \mathrm{LiPF}_{6} / 0.4 \mathrm{M} \\
\text { LiODFB salts }\end{array}$ & $\begin{array}{l}\mathrm{LiCoO}_{2} / \text { graphite full } \\
\text { cell }\end{array}$ & 152 & $\sim 90$ & $72 \%$ & $2 \mathrm{C}$ & [12] \\
\hline $\begin{array}{c}1 \mathrm{M} \mathrm{LiPF}_{6} \mathrm{P} 3-\mathrm{TFSI} / \mathrm{EC}(1 / 1) \\
w / w 5 \% \text { FEC }\end{array}$ & $\begin{array}{l}\text { Graphite/Li half } \\
\text { batteries }\end{array}$ & 115 & $\sim 100$ & $95 \%$ & $\mathrm{C} / 12$ & [13] \\
\hline $\begin{array}{l}\text { inorganic non-aqueous liquid } \\
\text { electrolyte- } \mathrm{LiAlCl}_{4,3} \mathrm{SO}_{2} \text { (IE) }\end{array}$ & $\mathrm{LiFePO} 4$ & 113 & $\sim 100$ & $94 \%$ & $5 \mathrm{C}$ & [14] \\
\hline 5.3 M LiFSA/TMP & $\begin{array}{l}\mathrm{LiNi}_{0.5} \mathrm{Mn}_{1.5} \mathrm{O}_{4} / \\
\text { graphite } / \mathrm{Li} \text { half } \\
\text { batteries }\end{array}$ & 250 & 1200 & $99 \%$ & $\mathrm{C} / 5$ & [23] \\
\hline ADN + LiTFSI & $\begin{array}{c}\mathrm{LiNi}_{1 / 3} \mathrm{Co}_{1 / 3} \mathrm{Mn}_{1 / 3} \mathrm{O}_{2} \\
\text { (NMC) }\end{array}$ & 165 & $\sim 200$ & $98 \%$ & $0.5 \mathrm{C}$ & [24] \\
\hline LiBOB-based electrolyte & $\begin{array}{l}\text { graphite } / \mathrm{LiCo}_{1 / 3} \mathrm{Mn}_{1 / 3} \\
\qquad \mathrm{Ni}_{1 / 3} \mathrm{O}_{2} \text { full cell }\end{array}$ & 108 & $\sim 500$ & $80 \%$ & $1 \mathrm{C}$ & [10] \\
\hline $\begin{array}{c}1 \mathrm{M} \mathrm{LiPF}_{6} \text { in FEC:FEMC:HFE } \\
(w / w / w=2 / 6 / 2)\end{array}$ & $\mathrm{Li} / \mathrm{LCP}$ cell & & 1000 & $93 \%$ & $1 C$ & [26] \\
\hline $\begin{array}{l}\text { 1:2 LiFSI-TEP with FEC-LiBOB } \\
\text { composite additives }\end{array}$ & $\mathrm{Li}-\mathrm{Cu}$ half cells & 135 & 350 & $88 \%$ & $0.05 \mathrm{C}$ & [27] \\
\hline $\begin{array}{l}1 \mathrm{M} \mathrm{Li}^{-\mathrm{LiPF}_{6}} \text { in } \mathrm{PC} \text { and } \\
\text { fluorinated linear carbonate } \\
\text { co-solvents }\end{array}$ & $\begin{array}{l}\text { LMNC/graphite full } \\
\text { cell }\end{array}$ & 250 & 100 & $72 \%$ & $0.2 \mathrm{C}$ & [28] \\
\hline $2 \mathrm{M} \mathrm{LiPF}_{6}$ in EC:DEC:TMP & $\mathrm{LiMn}_{2} \mathrm{O}_{4}$ cathode & 34 & 50 & $97 \%$ & $0.2 \mathrm{C}$ & [30] \\
\hline $\begin{array}{l}1 \mathrm{M} \mathrm{LiPF}_{6} \text { in TMS + } 10 \% \mathrm{VC} \\
\text { electrolyte }\end{array}$ & $\mathrm{LiNiO}_{2}$ & 145 & 195 & & & [33] \\
\hline $5 \mathrm{M} \mathrm{LiFSI/TMP}$ & $\mathrm{Li} / \mathrm{LiFePO}_{4}$ battery & 118 & 400 & $99 \%$ & $0.5 \mathrm{C}$ & {$[35]$} \\
\hline $\begin{array}{l}\text { GPE based on electro-spun } \\
\text { PVDF/HNT nano-composite } \\
\text { non-wovens }\end{array}$ & $\mathrm{LiCoO}_{2}$ & 138 & 50 & $97 \%$ & $0.1 \mathrm{C}$ & [41] \\
\hline P(MMA-AN-EA) + EMITFSI & $\mathrm{LiFePO}_{4}$ & & 100 & $95 \%$ & $0.2 \mathrm{C}$ & {$[13]$} \\
\hline GPE-SN-IM & $\begin{array}{l}\mathrm{LiCoO} 2 / \mathrm{Li}_{4} \mathrm{Ti}_{5} \mathrm{O}_{12} \\
\text { film battery }\end{array}$ & 132 & 100 & $92 \%$ & $0.2 \mathrm{C}$ & [42] \\
\hline $\begin{array}{l}\text { PAN/PVA (20:80 ratio) } \\
\text { blending membrane-based } \\
\text { GPE }\end{array}$ & $\mathrm{LiCoO}_{2}$ & 160 & 200 & $96 \%$ & $1 \mathrm{C}$ & [43] \\
\hline
\end{tabular}


Table 1. Cont

\begin{tabular}{|c|c|c|c|c|c|c|}
\hline Electrolyte Composition & $\begin{array}{l}\text { Cathode/Battery } \\
\text { Type }\end{array}$ & $\begin{array}{l}\text { Discharge } \\
\text { Capacity } \\
\left(\mathrm{mAh} \cdot \mathrm{g}^{-1}\right)\end{array}$ & $\begin{array}{l}\text { Number of } \\
\text { Cycles }\end{array}$ & $\begin{array}{l}\text { Capacity } \\
\text { Retention }\end{array}$ & Rate & Reference \\
\hline $\begin{array}{l}\text { IPN-GPE with } 1 \mathrm{M} \mathrm{LiPF}_{6} \text { in } \\
\text { EC/DMC/DEC } \frac{1}{4} 1 / 1 / 1 \\
v / v / v \text {, liquid electrolyte }\end{array}$ & $\mathrm{LiFePO}_{4}$ & 143 & 100 & $94 \%$ & & [44] \\
\hline 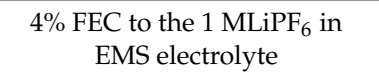 & NMC/graphite cells & 325 & 100 & $99 \%$ & $0.1 \mathrm{C}$ & [45] \\
\hline LFP/PDLLA-SPE/Li & $\mathrm{LiFePO}_{4}$ & 144.7 & 250 & $87 \%$ & & [46] \\
\hline $\begin{array}{c}1.0 \mathrm{M} \mathrm{LiPF}_{6} \text { in EC/DMC mixed } \\
\text { with } 700 \text { wt. } \% \text { polymer }\end{array}$ & $\begin{array}{l}\mathrm{LiCoO}_{2} / \text { graphite } \\
\text { electrodes }\end{array}$ & & 300 & $74 \%$ & $0.1 \mathrm{C}$ & [47] \\
\hline $\begin{array}{l}\text { ILGPEs supported by } 10 \% \\
\text { LAGP }\end{array}$ & $\mathrm{LiFePO}_{4}$ & 131 & 50 & & $0.05 \mathrm{C}$ & [48] \\
\hline PEM based on PEGBCDMA & $\mathrm{LiFePO}_{4}$ & 125 & 250 & $80 \%$ & $\mathrm{C} / 3$ & [49] \\
\hline $\begin{array}{l}\text { PAMM-based gel polymer } \\
\text { electrolyte }\end{array}$ & $\begin{array}{l}\mathrm{LiNi}_{0.5} \mathrm{Mn}_{1.5} \mathrm{O}_{4} / \mathrm{Li} \\
\text { and } \mathrm{LiNi}_{0.5} \mathrm{Mn}_{1.5} \mathrm{O}_{4} / \\
\mathrm{Li}_{4} \mathrm{Ti}_{5} \mathrm{O}_{12} \text { batteries }\end{array}$ & 128 & 100 & $96 \%$ & $0.1 \mathrm{C}$ & [50] \\
\hline $\begin{array}{l}\text { Solid polymer electrolyte: } \\
\text { PCL/SN blends with } \\
\text { PAN-skeleton }\end{array}$ & $\mathrm{LiFePO}_{4}$ & 101 & 400 & $100 \%$ & $1 \mathrm{C}$ & [51] \\
\hline $\begin{array}{c}40 \text { wt. } \% \mathrm{Mg}(\mathrm{OH})_{2} \text { added to } \\
\text { electrolyte }\end{array}$ & $\mathrm{LiCoO}_{2} /$ graphite & 112 & 200 & $83 \%$ & $0.5 \mathrm{C}$ & [52] \\
\hline Ionogel electrolyte & $\mathrm{LiFePO}_{4}$ & 136 & 200 & & & [53] \\
\hline $\begin{array}{c}\text { Tetra PEG gel mixed with } 1.0 \mathrm{M} \\
\mathrm{LiPF}_{6} \text { in an EC + DEC + TFEP } \\
\text { mixture }(v / v / v=53 / 27 / 20) \\
\text { electrolyte }\end{array}$ & $\mathrm{LiFePO}_{4}$ & 128 & 10 & $95 \%$ & $0.1 \mathrm{C}$ & [54] \\
\hline $\begin{array}{l}\text { PAEKNW) cross-linked with } \\
\text { poly(ethylene glycol) } \\
\text { dimethacrylate electrolyte }\end{array}$ & $\mathrm{LiFePO}_{4}$ & 128 & 200 & $90 \%$ & $1 \mathrm{C}$ & [55] \\
\hline 5 wt. $\%$ TFPCT & NCA/Li half-cell & 120 & 100 & $92 \%$ & $0.5 \mathrm{C}$ & [57] \\
\hline $\begin{array}{l}0.5 \% \text { DTYP additive in base } \\
\text { electrolyte }\end{array}$ & $\begin{array}{l}\mathrm{LiNi}_{0.5} \mathrm{Mnn}_{1.5} \mathrm{O}_{4} / \\
\text { graphite full cells }\end{array}$ & 125 & 280 & & $1 \mathrm{C}$ & [58] \\
\hline $\begin{array}{c}\text { poly (ethylene } \\
\text { oxide)-LiTFSi- } \mathrm{Mg}_{2} \mathrm{~B}_{2} \mathrm{O}_{5} \\
\text { electrolyte }\end{array}$ & $\mathrm{LiFePO}_{4}$ & 120 & 230 & & $1 \mathrm{C}$ & [59] \\
\hline $\begin{array}{l}5 \text { wt. \% PFN-containing } \\
\text { electrolyte }\end{array}$ & $\begin{array}{l}\mathrm{LiNi}_{0.5} \mathrm{Mn}_{1.5} \mathrm{O}_{4} \\
\text { cathode }\end{array}$ & $\sim 110$ & 100 & & $1 \mathrm{C}$ & [60] \\
\hline $5 \%$ PFPN & $\mathrm{LiCoO}_{2}$ & 150.7 & 30 & $99 \%$ & $0.1 \mathrm{C}$ & [61] \\
\hline 5 wt. $\%$ EEEP in electrolyte & $\mathrm{LiCoO}_{2}$ & & 100 & $91 \%$ & & [62] \\
\hline
\end{tabular}

\section{Conclusions and Future Direction}

Recently, numerous Li-ion battery fire and explosion incidents attracted attention to the issue of battery safety. In this paper, we discussed research conducted toward the development of non-flammable electrolytes to design safer batteries. The use of self-cooling and fire-retardant materials in electrolytes can be an attractive option. The use of fluorinated carbonates and ionic liquids can be potentially useful in designing safer batteries. A fire-extinguishing electrolyte with high cyclability is very interesting for high-performance rechargeable batteries. We hope this article will provide an insight into recent development for safer electrolytes and lithium ion batteries.

Author Contributions: Conceptualization, investigation, original draft preparation, writing review: N.C., editing, proofing \& visualization: N.B., S.S., N.C.

Funding: This research received no external funding.

Conflicts of Interest: The authors declare no conflict of interest. 


\section{Abbreviations}

The following abbreviations are used in this manuscript:

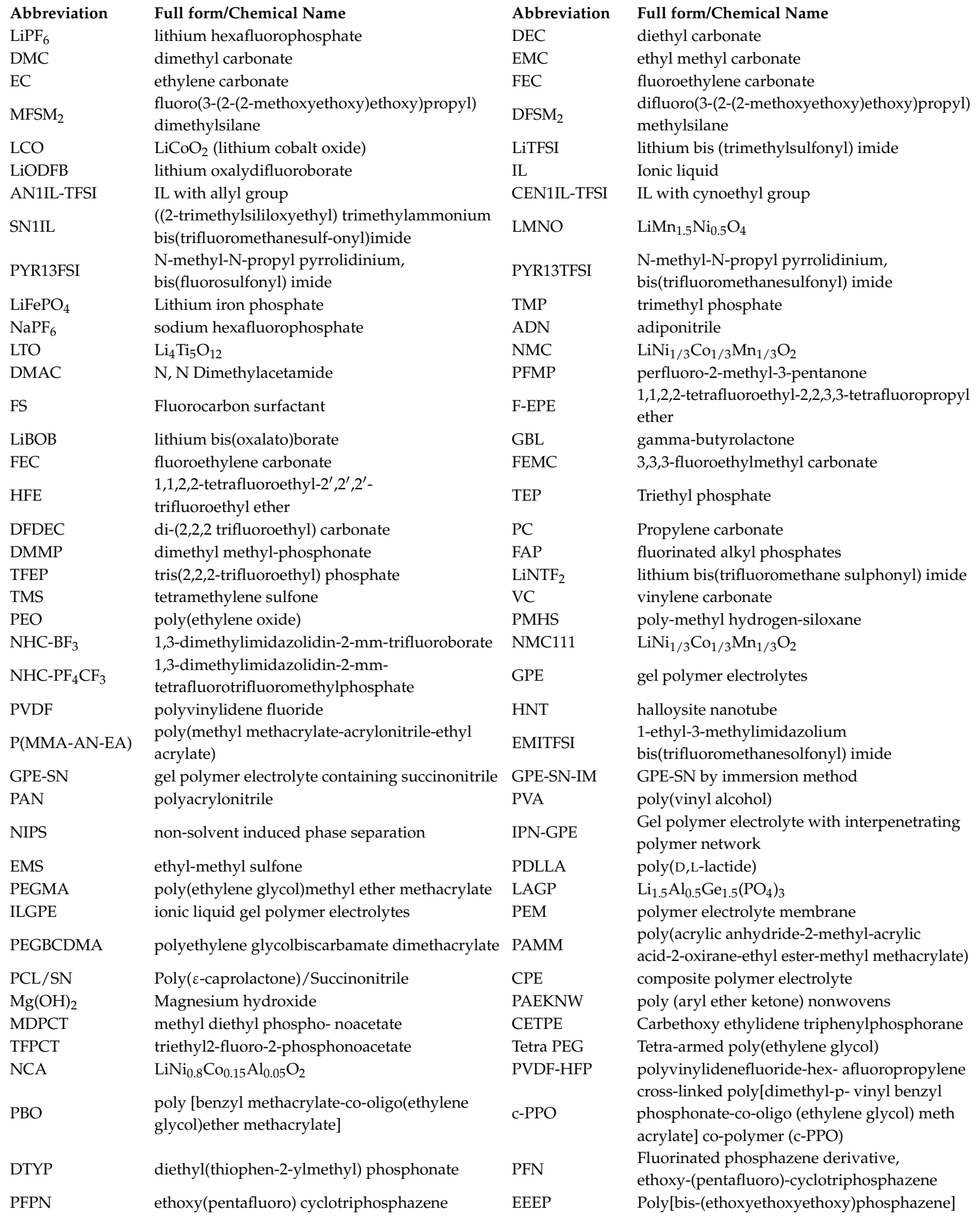

\section{References}

1. Hahn, M.; Wieboldt, D.; Ruff, I. Techniques for Raman Analysis of Lithium-Ion Batteries. Spectroscopy 2015, 30, 1-3.

2. Samuelson, K. A Brief History of Samsung's Troubled Galaxy Note 7 Smartphone. 2016. Available online: http:// time.com/4526350/samsung-galaxy-note-7-recall-problems-overheating-fire/ (accessed on 11 November 2017). 
3. Pappalardo, J. No One is Fixing Flying's Fire Problem. 2018. Available online: https:/ / www.popularmechanics. com/flight/airlines/a22629210/faa-laptop-battery-fire-danger-regulations/ (accessed on 3 August 2018).

4. Jansen, B. Crash investigators trace UPS plane fire to batteries. USA TODAY, 25 July 2013.

5. Exploding Camera Battery Causes Panic at Orlando International Airport, Police Say. 2017. Available online: https:/ / www.wftv.com/news/local/exploding-camera-battery-causes-panic-at-orlando-internationalairport-police-say / 645230506 (accessed on 11 November 2017).

6. Economy, P. Lithium-Ion Battery on Delta Air Lines Flight Explodes, Catches Fire (Quick-Thinking Crew Averts Disaster). Available online: https:/ / www.inc.com/peter-economy/lithium-ion-battery-on-delta-airlines-flight-explodes-catches-fire-quick-thinking-crew-averts-disaster.html (accessed on 18 May 2018).

7. Loveday, E. Tesla Model S Catches Fire During Test Drive In France. Electrek, 15 August 2016.

8. Lambert, F. Tesla Model S battery caught on fire "without accident", says owner-Tesla is investigating. Electrek, 16 June 2018.

9. Jiang, L.; Wang, Q.; Li, K.; Ping, P. A self-cooling and flame-retardant electrolyte for safer lithium ion batteries. Sustain. Energy Fuels 2018, 2, 1323-1331. [CrossRef]

10. Shi, P.; Fang, S.; Huang, J.; Luo, D.; Yang, L.; Hirano, S. A novel mixture of lithium bis(oxalato)borate, gamma-butyrolactone and non-flammable hydrofluoroether as a safe electrolyte for advanced lithium ion batteries. J. Mater. Chem. A 2017, 5, 19982-19990. [CrossRef]

11. Wang, J.; Mai, Y.; Luo, H.; Yan, X.; Zhang, L. Fluorosilane compounds with oligo (ethylene oxide) substituent as safe electrolyte solvents for high-voltage lithium-ion batteries. J. Power Sources 2016, 334, 58-64. [CrossRef]

12. Yong, T.; Zhang, L.; Wang, J.; Mai, Y.; Yan, X. Novel choline-based ionic liquids as safe electrolytes for high-voltage lithium-ion batteries. J. Power Sources 2016, 328, 397-404. [CrossRef]

13. Salem, N.; Abu-lebdeh, Y. Non-Flammable Electrolyte Mixtures of Ringed Ammonium-Based Ionic Liquids and Ethylene Carbonate for High Voltage Li-Ion Batteries. J. Electrochem. Soc. 2014, 161, A1593-A1601. [CrossRef]

14. Gao, T.; Wang, B.; Wang, L.; Liu, G.; Wang, F.; Luo, H.; Wang, D. $\mathrm{LiAlCl}_{4} \cdot 3 \mathrm{SO}_{2}$ as a high conductive, non-flammable and inorganic non-aqueous liquid electrolyte for lithium ion batteries. Electrochim. Acta 2018, 286, 77-85. [CrossRef]

15. Safa, M.; Chamaani, A.; Chawla, N.; El-Zahab, B. Polymeric Ionic Liquid Gel Electrolyte for Room Temperature Lithium Battery Applications. Electrochim. Acta 2016, 213, 587-593. [CrossRef]

16. Ceder, G.; Supervisor, T.; Schuh, C. First Principles Design and Investigation of Lithium-Ion Battery Cathodes and Electrolytes. Ph.D. Dissertation, Massachusetts Institute of Technology, Cambridge, MA, USA, 2011.

17. Li, M.; Liao, Y.; Liu, Q.; Xu, J.; Sun, P.; Shi, H. Application of the imidazolium ionic liquid based nano-particle decorated gel polymer electrolyte for high safety lithium ion battery. Electrochim. Acta 2018, 284, 188-201. [CrossRef]

18. Moreno, M.; Simonetti, E.; Appetecchi, G.B.; Carewska, M.; Montanino, M.; Kim, G.; Loeffler, N.; Passerini, S. Ionic Liquid Electrolytes for Safer Lithium Batteries I. Investigation around Optimal Formulation. J. Electrochem. Soc. 2017, 164, 6026-6031. [CrossRef]

19. Feng, J.; Zhang, Z.; Li, L.; Yang, J.; Xiong, S.; Qian, Y. Ether-based nonflammable electrolyte for room temperature sodium battery. J. Power Sources 2015, 284, 222-226. [CrossRef]

20. Wang, X.; Yasukawa, E.; Kasuya, S. Nonflammable trimethyl phosphate solvent-containing electrolytes for lithium-ion batteries: I. Fundamental properties. J. Electrochem. Soc. 2001, 148, A1058-A1065. [CrossRef]

21. Shim, E.G.; Nam, T.H.; Kim, J.G.; Kim, H.; Moon, S. Effect of the concentration of diphenyloctyl phosphate as a flame-retarding additive on the electrochemical performance of lithium-ion batteries. Electrochim. Acta 2009, 54, 2276-2283. [CrossRef]

22. Nakagawa, H.; Ochida, M.; Domi, Y.; Doi, T.; Tsubouchi, S.; Yamanaka, T.; Abe, T.; Ogumi, Z. Electrochemical Raman study of edge plane graphite negative-electrodes in electrolytes containing trialkyl phosphoric ester. J. Power Sources 2012, 212, 148-153. [CrossRef]

23. Wang, J.; Yamada, Y.; Sodeyama, K.; Watanabe, E.; Takada, K.; Tateyama, Y.; Yamada, A. Fire-extinguishing organic electrolytes for safe batteries. Nat. Energy 2018, 3. [CrossRef] 
24. Co, L.; Nmc, M.O. Adiponitrile-Lithium Bis(trimethylsulfonyl)imide Solutions as Alkyl Carbonate-free Electrolytes for $\mathrm{Li}_{4} \mathrm{Ti}_{5} \mathrm{O}_{12}$ (LTO)/ $\mathrm{LiNi}_{1 / 3} \mathrm{Co}_{1 / 3} \mathrm{Mn}_{1 / 3} \mathrm{O}_{2}$ (NMC) Li-Ion Batteries. ChemPhysChem 2017, 12 , 1333-1344. [CrossRef]

25. Shi, P.; Fang, S.; Luo, D.; Yang, L.; Hirano, S. A Safe Electrolyte Based on Propylene Carbonate and Non-Flammable Hydrofluoroether for High-Performance Lithium Ion Batteries. J. Electrochem. Soc. 2017, 164, 1991-1999. [CrossRef]

26. Fan, X.; Chen, L.; Borodin, O.; Ji, X.; Chen, J.; Hou, S.; Deng, T.; Zheng, J.; Yang, C.; Liou, S.; et al. batteries with aggressive cathode chemistries. Nat. Nanotechnol. 2018, 13. [CrossRef]

27. Zeng, Z.; Murugesan, V.; Han, K.S.; Jiang, X.; Cao, Y.; Xiao, L. Non-flammable electrolytes with high salt-to-solvent ratios for Li-ion and Li-metal batteries. Nat. Energy 2018, 3. [CrossRef]

28. Quang, H.; Lee, H.; Hwang, E.; Kwon, Y.; Song, S. Non-flammable organic liquid electrolyte for high-safety and high-energy density Li-ion batteries. J. Power Sources 2018, 404, 13-19. [CrossRef]

29. Wang, X.; Yamada, C.; Naito, H.; Segami, G.; Kibe, K. High-Concentration Trimethyl Phosphate-Based Nonflammable Electrolytes with Improved Charge-Discharge Performance of a Graphite Anode for Lithium-Ion Cells. J. Electrochem. Soc. 2006, 153, 135-139. [CrossRef]

30. Matsumoto, K.; Nakahara, K.; Inoue, K.; Iwasa, S. Performance Improvement of Li Ion Battery with Non-Flammable TMP Mixed Electrolyte by Optimization of Lithium Salt Concentration and SEI Preformation Technique on Graphite Anode. J. Electrochem. Soc. 2014, 161, 831-834. [CrossRef]

31. Dalavi, S.; Xu, M.; Ravdel, B.; Zhou, L.; Lucht, B.L. Nonflammable Electrolytes for Lithium-Ion Batteries. J. Electrochem. Soc. 2010, 157. [CrossRef]

32. Marinov, Y.; Aoki, M.; Mimura, H.; Fujii, K.; Yoshimoto, N.; Morita, M. Thermal and electrochemical properties of nonflammable electrolyte solutions containing fluorinated alkylphosphates for lithium-ion batteries. J. Power Sources 2016, 332, 322-329. [CrossRef]

33. Kurc, B. Electrolyte Working in a lithium-ion batteries with a $\mathrm{LiNiO}_{2}$ Cathode. J. Phys. Chem. Lett. 2018, 13, 5938-5955. [CrossRef]

34. Li, Y.; Fan, C.; Zhang, J.; Wu, X. A promising PMHS/PEO blend polymer electrolyte for all-solid-state lithium ion batteries. Dalton Trans. 2018, 47, 14932-14937. [CrossRef] [PubMed]

35. Shi, P.; Zheng, H.; Liang, X.; Sun, Y.; Cheng, S.; Chen, C.; Xiang, H. A highly concentrated phosphate-based electrolyte for high-safety rechargeable lithium batteries. Chem. Commun. 2018, 54, 4453-4456. [CrossRef] [PubMed]

36. Janssen, P.; Streipert, B.; Krafft, R.; Murmann, P.; Wagner, R.; Winter, M.; Cekic-laskovic, I. Shutdown potential adjustment of modi fi ed carbene adducts as additives for lithium ion battery electrolytes. J. Power Sources 2017, 367, 72-79. [CrossRef]

37. Chamaani, A.; Safa, M.; Chawla, N.; El-Zahab, B. Composite Gel polymer electrolyte for improved cyclability in lithium-oxygen batteries. ACS Appl. Mater. Interfaces 2017, 9, 33819-33826. [CrossRef] [PubMed]

38. Safa, M.; Hao, Y.; Chamaani, A.; Adelowo, E.; Chawla, N.; Wang, C.; El-Zahab, B. Capacity Fading Mechanism in Lithium-Sulfur Battery using Poly(ionic liquid) Gel Electrolyte. Electrochim. Acta 2017, 258, 1284-1292. [CrossRef]

39. Chamaani, A.; Chawla, N.; Safa, M.; El-Zahab, B. One-Dimensional Glass Micro-Fillers in Gel Polymer Electrolytes for $\mathrm{Li}_{2} \mathrm{O}_{2}$ Battery Applications. Electrochim. Acta 2017, 235, 56-63. [CrossRef]

40. Chamaani, A.; Safa, M.; Chawla, N.; Herndon, M.; El-zahab, B. Stabilizing e ff ect of ion complex formation in lithium-Oxygen battery electrolytes. J. Electroanal. Chem. 2018, 815, 143-150. [CrossRef]

41. Khalifa, M.; Janakiraman, S.; Ghosh, S.; Venimadhav, A.; Anandhan, S. PVDF/Halloysite Nanocomposite-Based Non-Wovens as Gel Polymer Electrolyte for High Safety Lithium Ion Battery. Polym. Compos. 2018, 1-15. [CrossRef]

42. Lv, P.; Li, Y.; Wu, Y.; Liu, G.; Liu, H.; Li, S.; Tang, C.; Mei, J.; Li, Y. Robust Succinonitrile-Based Gel Polymer Electrolyte for Lithium-Ion Batteries Withstanding Mechanical Folding and High Temperature. ACS Appl. Mater. Interfaces 2018, 10, 25384-25392. [CrossRef] [PubMed]

43. He, C.; Liu, J.; Li, J.; Zhu, F.; Zhao, H. Blending based polyacrylonitrile/poly (vinyl alcohol) membrane for rechargeable lithium ion batteries. J. Memb. Sci. 2018, 560, 30-37. [CrossRef] 
44. Huang, B.; Zhang, Y.; Que, M.; Xiao, Y.; Jiang, Y.; Yuan, K.; Chen, Y. A facile in situ approach to ion gel based polymer electrolytes for flexible lithium batteries. RSC Adv. 2017, 7, 54391-54398. [CrossRef]

45. Hilbig, P.; Ibing, L.; Wagner, R.; Winter, M.; Cekic-Laskovic, I. Ethyl Methyl Sulfone-Based Electrolytes for Lithium Ion Battery Applications. Energies 2017, 10, 1312. [CrossRef]

46. Wang, B.; Lou, H.; Xu, H.; Zhao, J.; Wang, Q.; Shi, Q.; Deng, Y. High voltage, solvent-free solid polymer electrolyte based on a star-comb PDLLA-PEG copolymer for lithium ion batteries. RSC Adv. 2018, 8, 6373-6380. [CrossRef]

47. Young, J.; Ok, D.; Kim, S.; Ho, J.; Man, K.; Oh, J.; Kim, J.; Ju, M.; Yang, Y.; Lee, S.; et al. Reversible thixotropic gel electrolytes for safer and shape-versatile lithium- ion batteries. J. Power Sources 2018, 401, 126-134. [CrossRef]

48. Guo, Q.; Han, Y.; Wang, H.; Xiong, S.; Sun, W.; Zheng, C.; Xie, K. Liquid Gel Polymer Electrolytes for High Safety Rechargeable Solid- State Lithium Metal Batteries. J. Phys. Chem. C 2018, 122, 10334-10342. [CrossRef]

49. Fu, G.; Soucek, M.D.; Kyu, T. Fully flexible lithium ion battery based on a flame retardant, solid-state polymer electrolyte membrane. Solid State Ionics 2018, 320, 310-315. [CrossRef]

50. Ma, Y.; Ma, J.; Chai, J.; Liu, Z.; Ding, G.; Xu, G.; Liu, H. Two Players Make a Formidable Combination: In Situ Generated Poly(acrylic anhydride-2-methyl-acrylic acid-2-oxirane-ethyl ester-methyl methacrylate) Cross-Linking Gel Polymer Electrolyte toward 5 V High-Voltage Batteries. Appl. Mater. Interfaces 2017, 9, 41462-41472. [CrossRef] [PubMed]

51. Zhang, D.; Zhang, L.; Yang, K.; Wang, H.; Yu, C.; Xu, D.; Xu, B.; Wang, L. Superior Blends Solid Polymer Electrolyte with Integrated Hierarchical Architectures for All-Solid-State Lithium-Ion Batteries. Appl. Mater. Interfaces 2017, 9, 36886-36896. [CrossRef] [PubMed]

52. Kim, S.; Han, T.; Jeong, J.; Lee, H.; Ryou, M.; Min, Y. A Flame-Retardant Composite Polymer Electrolyte for Lithium-Ion Polymer Batteries. Electrochim. Acta 2017, 241, 553-559. [CrossRef]

53. Wu, F.; Zhu, Q.; Chen, R.; Chen, N.; Chen, Y.; Ye, Y. Ionic liquid-based electrolyte with binary lithium salts for high performance lithium e sulfur batteries. J. Power Sources 2015, 296, 10-17. [CrossRef]

54. Han, J.; Saka, T.; Yosh, N.; Fuj, K. Electrochemical Properties of a Tetra PEG-based Gel Electrolyte Containing a Nonflammable Fluorinated Alkyl Phosphate for Safer Lithium-ion Batteries. Chem. Lett. 2018, 909-912. [CrossRef]

55. Li, G.; Chen, X.; Miao, L.; Chen, J.; Zheng, J. A hybridized solid-gel nonflammable Li-Battery. J. Power Sources 2018, 394, 26-34. [CrossRef]

56. Jia, H.; Onishi, H.; Wagner, R.; Winter, M.; Cekic-laskovic, I. Intrinsically Safe Gel Polymer Electrolyte Comprising Flame- Retarding Polymer Matrix for Lithium Ion Battery Application. ACS Appl. Mater. Interfaces 2018, 10, 42348-42355. [CrossRef] [PubMed]

57. Liu, L.; Du, C.; Wang, S.; Chen, S. Three new bifunctional additive for safer nickel-cobalt-aluminum based lithium ion batteries. Chin. Chem. Lett. 2018, 2-5. [CrossRef]

58. Zhu, Y.; Luo, X.; Zhi, H.; Liao, Y.; Xing, L.; Xu, M.; Liu, X.; Xu, K.; Li, W. Diethyl(thiophen-2-ylmethyl)phosphonate: A novel multifunctional electrolyte additive for high voltage batteries. J. Mater. Chem. A 2018, 6, 10990-11004. [CrossRef]

59. Sheng, O.; Jin, C.; Luo, J.; Yuan, H.; Huang, H.; Gan, Y.; Zhang, J.; Xia, Y.; Liang, C.; Zhang, W.; et al. $\mathrm{Mg}_{2} \mathrm{~B}_{2} \mathrm{O}_{5}$ Nanowire Enabled Multifunctional Solid-State Electrolytes with High Ionic Conductivity, Excellent Mechanical Properties, and Flame-Retardant Performance. Nano Lett. 2018, 18, 3104-3112. [CrossRef] [PubMed]

60. Liu, J.; Song, X.; Zhou, L.; Wang, S.; Song, W.; Liu, W.; Long, H. Nano Energy Fluorinated phosphazene derivative-A promising electrolyte additive for high voltage lithium ion batteries: From electrochemical performance to corrosion mechanism. Nano Energy 2018, 46, 404-414. [CrossRef]

61. Li, X.; Li, W.; Chen, L.; Lu, Y.; Su, Y.; Bao, L.; Wang, J. Ethoxy (penta fluoro) cyclotriphosphazene (PFPN) as a multi-functional flame retardant electrolyte additive for lithium-ion batteries. J. Power Sources 2018, 378, 707-716. [CrossRef] 
62. Zhou, M.; Qin, C.; Liu, Z.; Feng, L.; Su, X.; Chen, Y.; Xia, L.; Xia, Y.; Liu, Z. Applied Surface Science Enhanced high voltage cyclability of $\mathrm{LiCoO}_{2}$ cathode by adopting poly [bis-(ethoxyethoxyethoxy) phosphazene] with flame-retardant property as an electrolyte additive for lithium-ion batteries. Appl. Surf. Sci. 2017, 403, 260-266. [CrossRef]

63. Sun, W.; Suo, L.; Wang, F.; Eidson, N.; Yang, C.; Han, F.; Ma, Z.; Gao, T.; Zhu, M.; Wang, C. “Water-in-Salt” electrolyte enabled $\mathrm{LiMn}_{2} \mathrm{O}_{4} / \mathrm{TiS}_{2}$ Lithium-ion batteries. Electrochem. Commun. 2017, 82, 71-74. [CrossRef]

(C) 2019 by the authors. Licensee MDPI, Basel, Switzerland. This article is an open access article distributed under the terms and conditions of the Creative Commons Attribution (CC BY) license (http:/ / creativecommons.org/licenses/by/4.0/). 